University of Louisville

ThinkIR: The University of Louisville's Institutional Repository

$5-1948$

\title{
A study of prematurely and routinely discharged patients from Louisville General Hospital in 1946.
}

Ruth Coleman Davidson

University of Louisville

Follow this and additional works at: https://ir.library.louisville.edu/etd

Part of the Social Work Commons

\section{Recommended Citation}

Davidson, Ruth Coleman, "A study of prematurely and routinely discharged patients from Louisville General Hospital in 1946." (1948). Electronic Theses and Dissertations. Paper 1890.

https://doi.org/10.18297/etd/1890

This Master's Thesis is brought to you for free and open access by ThinkIR: The University of Louisville's Institutional Repository. It has been accepted for inclusion in Electronic Theses and Dissertations by an authorized administrator of ThinkIR: The University of Louisville's Institutional Repository. This title appears here courtesy of the author, who has retained all other copyrights. For more information, please contact thinkir@louisville.edu. 


\title{
ONIVIRSITI OF LOUISVIILA
}

A STUDY OF PRHAMTURBLY AND ROUTINBLY DISCHARGRD PATIFNTS

FROY LOUISVILLE GFNERAL HOSPITAL DN 1946

\author{
A Dissertation \\ Submitted to the Faculty \\ of the Raymond A. Kent School of Social Work \\ University of Louistile \\ In Partial Fulfillment of the \\ Requirements for the Degree \\ Of Naster of Science in Social Wark
}

By

Ruth Coleman Davidson

Yoar

1948 


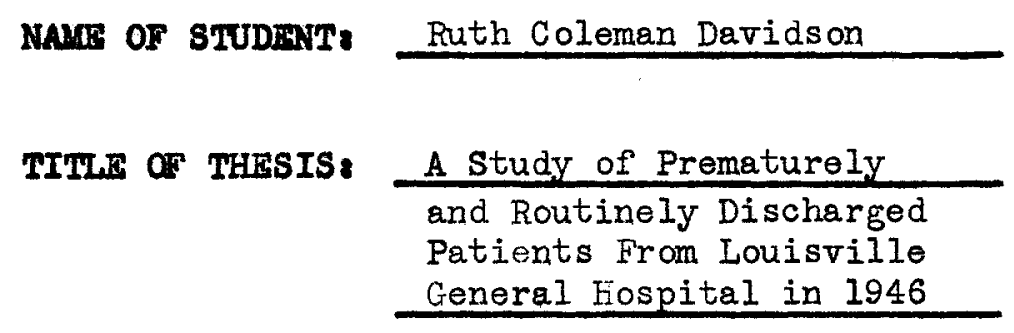

APPROVED BY RFADING COMMITTRE COLPOSED OF THE FOLLONING LAMBBRS:

Howell V. Williams

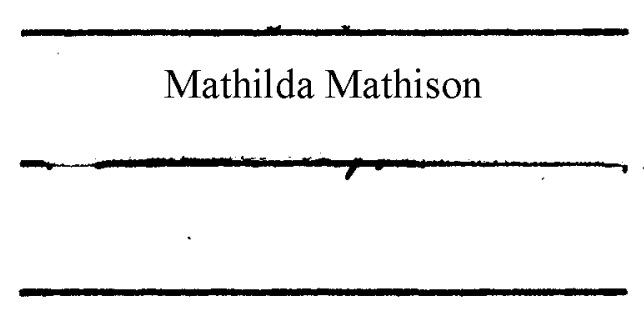

NAME OF DEAN: Howell V. Willisms

DATE: May 20, 1948 


\section{ACKONOWLFDGER IFHTS}

For their help in determining the scope of this atudy of prematurely and routinely discherged patients at Louisville General Hospital, the investigator wishes to express her appreciation to the former dean of Kent School of Social Work, John J. Cronin, and to Professor Vathilda Kathison. Dr. R. I. Kutak of the Sociology Department of the University of Louisville was most helpful in oveluating the first and second drafts of the study in collaboration with the Kont School faculty.

Miss Evelyn Phelps, Director of Social Service Department at Louisville Genoral Hospital, during the period of study, was most helpful in suggesting appropriate areas and means of study. The helpful comments and material furnishod by $\mathbf{M r}$. Walton, Hospital Administrator at General Hospital during the curtailmont plan, and by Dr. John Phair of the Louisville and Jefferson County Health Department, further delineated the problem as well as some of the results for the hospitals as a whole of the curtailment policy begun in July 1946.

For his holp in criticizing and rovising certain aspocts of the study, especially those pertaining to genoral conditions on surgery servioe and the incidence and typical length of stay por diagnosis, the inreatigator is grateful to Dr. F. Vincent, Chiof Resident on Surgery at the time of the study. As bibliography was unobtainable on some aspects, this modical opinion was of holp in tosting the validity of the study.

Appreciation is due Miss Nellie Combs and her staff at Social Service Fxchange who reported all the registrations for the one hundred families where patients were discharged prematurely. The staff of the record roon of Goneral Hospital undor the leadership of Miss Edith Froy were also very helpful to the investigator in locating modical records.

The patients themeelves and their families, who gave generously of their time to individual interviews, finally made tho study possible. The investigator wishes to acknowledge their cooperativeness and helpfulnoss.

For his work on the final revision and helpfulness to the investigator in concluding the work on the study, sincere appreciation is due Dr. Howell K. Williams, Dean of Kent School of Social Work. 
TABLE OF CONTHENS

LIST OF TABLES

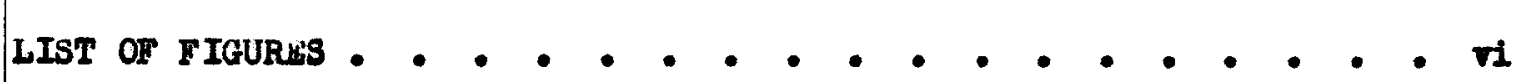

Chapter

I. HISTORICAL BACKGROUND OF CURTAILMANT POLICY OF LOUISVIILIT AND JEHTRRSON COUNTY HEALTH DIPARTMENT AND METHODOLOGY OF A STUDY OF PRAMATURMY AND ROUTINIRLY DISGHARGED PATIFNTS FROY LOUIS-

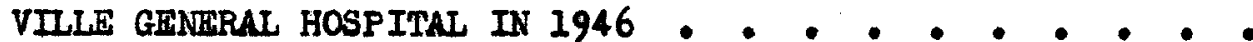

History of Curtailment in Health Department

The Policy of Promature Discharge

II. COMPARISON OF ONE HUNDRIDD PREMATURRLY DISCHARGED PATIENTS

VITH ONR HUNDRED ROUTINELY DISCHARGED PATIFNTS AT LOUIS-

VIILE GFNERAL HOSPITAL

Statiatics on Length of Hospital Stay for Study and Control Groups

Incidence of Readmissions for Recurrences of Original Illnes8

The Clinic Care of Study and Control Groups at Louisvilie

General Hospital, Discharged During July and August 1946

III. A SUMMARY OF FINDINGS . . . . . . . . . . 70

APPFNDIXES . . . . . . . . . . . . . 79

BIBLIOGRAPHY . . . . . . . . . . . . . . 95 


\section{LIST OF TABLES}

Table

1. Race and Sex of One thudred Patients of Louisville General Hospital Surgical Wards Prematurely Discharged During July and August 1946 Compered with Ono Hundred Patients Discharged Routinoly in Samo Period . . . . . . . . . 23

2. Age Distribution of One Hundred Prematurely Discharged Patients and of Ono Hundred Routinely Discharged Patients from Louieville General Hospital in July 1946 • • . . . 24

3. Length of Hospitel Stay for One Hundred Patients Promaturely Discharged from Louisville General Hospitel, July 1946, According to Special Surgical Service. . . . . . . . 30

4. Length of Hospital Stay for One Hundred Patients Routinely Discharged from Louisvill General Hospital, July 1946, According to Special Surgical Service. - . - . - . 31

5. Gonoral Hos pital'" Surgical Services on Which One Hundred Prematurely Discharged Patients and One Hundred Routinely Discharged Patients wore Admitted in July 1946. • . • . 34

6. Incidence of Diegnoses by Type of Surgical Specialty for One Hundred Patients Prematurely Discharged in July and August 1946 Showing Longth of Average Stay and Total Days Stay per Diagnostic Group

Part I General Surgery . . . . . . . . . . 44

Part II Orthopedic Service... . . . . . . . 45

Part III Gynocology. . . . . . . . . . . . . . 46

Part IV General Medicine, Eye, Proctology, Genito-Urinary Sorvices . . . . . . . . . . . 47

7. Incidence of Diagnostic Groupinge by Special Type of Surgery for One Hundred Patients Routinely Discharged in July and Auguat 1946 Showing Longth of Stay (Average) and Total Stay per Diagnostic Group at Louisville General Hospital

Part I General Surgery . . . . . . . . . 48

Part II Orthopedics . . . . . . . . . . . 49

Part III Gynocology - . . . . . . . . . . 50 
Table

Part IV General Medicine, Bye, Proctology, Genito-Urinary,

Neuro-Surgery Services . . . . . . . . 51

8. Length of Post-Operative Stay for Seventy Pationts of One Hundred Prematurely Discharged Patients from Surgicel Wards at Louisville General Hospital July 1946 Showing Totals by Colored and Wite Male and Femalo Wards and Hospital Stay by

Intervels of Three Daye . . . . . . . . . . 54

9. Distribution of Hospital Days Stay for Twelve Prematurely Discharged Patients and for Rleven Routinely Discharged Patients Readmitted to Louisvillo Genoral from July 1946 through January 1947

10. Number of Clinic Viaits for Seventy Prematurely Discharged Patients and for Sixty-Six Routinely Discharged Patients of Louisville General Hospital Surgery Wards from July 1946 through January 1947. . . . . . . . . . . . .

11. Diagnoses Causing the Most Frequent Clinic Visits for Ono Hundred Prematurely Discharged Patients from Louisville Goneral Hospital July 1946 and One Hundred Routinoly Discharged Patiento with Reference to the Spocial Surgical Service. . . . . . . . . . . . . . . 68

TABLES IN APPENDIXES

1. Monthly Statistics on Number of Pationts Prematurely and Routinely Discharged from Louisville General Hospital July 1946-April 1947. - . . . . . . . . . . .

2. Monthly Statistics on Average Length of Hospitalization for Routinely and Prematurely Discharged Patients from Louisville General Hospital July 1946-April 2947 • • • 80

3. Yonthly Statistics-Comparison of 1946-1947 Curtailment with 1940, 1945 Statist1cs. - . . . . . . . . . 81

4. Length of Hospital Stay for Selected Diagnostic Groups of Patients at Louisville General Hospital July-August 1946 Compared with Patients in Voluntary and Municipal Hospitals in New York City 1933 


\section{LIST OF FIGURES}

Pigure

1. One Hundred Prematurely Discharged Patients Compared with One Hundred Routinely Discharged Patients from Louisvilio Goneral Hospital in July 1946 by Age Distribution . • . . 25

2. Comparison of Prematurely and Routinely Discharged Patients by Number of Patients Admitted to Surgical Services at Louisville General Hospital July 1946 . . . . . . . 36

3. Average Stay per Surgical Service of Study and Control Groups - 52

4. Readmisgions for Twelve Prematurely Discharged Patients . . 60

5. Readmissions for Hheren Routinely Discharged Patients . • • . 61

\section{FIGURES IN APPENDIXES}

1. Organization of Louisvillo Health Department and City

Hoepitel before Merger with Jeffers on County Health Departmont . . . . . . . . . . . . . . . . 83

2. Organization of Louisville and Jefferson County Board of Health General Hospital and Waverly Hills Sanatorium after Merger of Louisvilie and Jefferson County Health Departments. - 84

3. Number of Patients by Special Divisions of Surgery Service Louisville General Hospital for 315 Prematurely Discharged Patiente July 1946-January 1947 . . . . . . . . . 85

4. Pationt 8 Known to Social Service Flechange Prior to 1945 Comparing Health and Welfare Agencies . . . . . . . . 90

5. One Hundred Prematurely Discharged Patients Known to Health and velfare Agencies Prior to 1945 and After 1945 - . . . 91

6. Patients Known to Social Service Hxchange to Health Agencies and Social Agencies During 1945-1946-1947. 
7. Health Agencies and Social Agencios Regietering on One Hundred Prematurely Discharged Pationts from Louisvillo General Hospital July 1946-February 1947

8. Seventy-Four Prematurely Discharged Patients from General Hospitel Showing Percontage Working and Porcontage Satisfied with Care. . . . . . . . . . . . . . 94 


\section{CHAPTIR I}

HISTORICAL BAGKGROUND OF CURTAIIMANT POLICY OF LOUISVITIE

AND JEFFERSON COUNTY HEALTH DEPARTMENT AND METHODOLOGY

OF A STUDY OF PRFMATUREI Y AND ROUTINELY DISCHARGED

PATIENTS BROY LOUISVIILE GRNBRAL HOSPITAL IN 1946

In July 1946 the Board of Health of Louieville and Jefferson County, Kentucky, announced its decision to curtail services of the pubIic health department serving the metropolitan area surrounding and including Louisville, and the outlying agricultural rogion in the rural part of Jefferson County. In the past decade the combined health department for Louisville and for Jefferson County had accomplished much for the health needs of the citizens of the comnunity. The close association, as a teaching hospital, with the Univeraity of Louisville Medical School, had helped General Hospital, the former municipal hospitel known as City Hospital, I to become a good general hospital with fairly adequate ward and clinic facilities.

Therefore, it was with regret that the Health Board decided to curtail service just when it was most noeded, as returning servicemen, and now family groups; industrial workers attracted by new industry

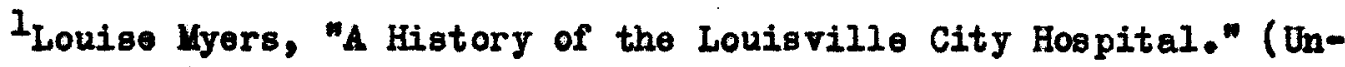
published Naster's thosis, Department of History, University of Louisजillo, 1940.) 
loosting in Louisville and the surrounding countys and families attracted by the expansion of business in the growing metropolitan area, made Louisville an increasingly important city in the nation.

After curtailment had beon announced as a definite policy of the administration of the ontire health department, and five wards at Genoral Hospitel had been closed, as a part of this plan, there doveloped another importent practice. This was the practice of discharging patients prematurely, or before the doctor or resident in charge of the ward had indicatod thoy should be ready to loave tho hospital. Premature discharge had to be adopted for reasons which will be doreloped later in the study, but it had certain implications for the ataff and for the patients who were so discharged. The effects on hospital administration and on sample group of pationts will be considored.

Premature discharge developed as a definite policy of the medical staff and of the hospital administration, so as to make the hospital's facilities stretch as far a possible under drastic curteliment of space and service. As a policy it has never been accepted as correct by the administration, the Hoalth Board, or the modical and nursing taff. The reality of the aituation in the hospitel made this, or some other drastic moasures necessary, if the adminiatration of the hospital was to accomplish the degreo of curtailment and still keop up reasonable coverage of the acutely ill population and maintain nearly-adequate standards of modical care.

A study was made of the pationts discharged prematurely since the curtailment plan wont into full offect in July 1946. The facts pertaining 
to this sample group were compared with those of a control group of patients routinely discharged during the same period. The purposes were to discover just what had happened to patients who were prematurely discharged, to what extent their medical care was completed through clinic care or by readmissions. The other purpose of the study was to discover and analyze, insofar as possible after a period of nino or ten months of curtailment and premature discharging, what the results had been to the patients at General Hospital. I'or these purposes material from General Hospital records were made available by the hospital administration and modical staff. It was possible to compare some itoms in the care and results of medical care botweon the atudy group of prematurely discharged patients and the control group of routinely discharged pationts. In the control group it was not possible to visit the patients, but their medical records were atudied. The study group of prematurely discharged patients were studied more thoroughly through thoir medical records, interviews with them, and some discussion with their doctors at General Hospital, if the situation was a peculiarly difficult one to treat modically. From this group of patients much material was obtained on the meaning of illness, but is not included in the presentation of the study material because it does not bear directly on the problem of curtailment or prenature discharge.

Case selection was made by taking the first one hundred names listed in the ward books on surgery, both white and colored, male and female wards. These rocords were all marked "premature discharge" by the doctors wen the patients left the hospital in July or August 1946 . It 
was decided to study only surgical pationts because for modical pationts woro discharged prematurely, and very fow pediatric cases were so disoharged oarly in the period under study. The maternity cases on obstetrics service, however, were alnost uniformly discharged prematurely, except in cases of serious complications of pregnancy, labor or birth. Since there could be no control group set up from maternity service because there were almost no routinely discharged patients on this service, this group of patients could not be used for study. The surgical patients were also more homogenous in age distribution, and the color and sex ratiog were well-balanced.

The material relating to average length of hoopitalisation, and to special diagnoses, was discussed with the hoad resident on surgery at General Hospital. Modical-social aspects of the curtailment measures were discussed and analyzed, with hospital adminigtrative problems in mind.

In several cases the social agency active on a patient was telophoned for additional information about him, and Social Service Departmont at General Hospital was asked for confirming details on what had happened to a fow patients known to them. It was surprising how fow of the prematurely discharged group had been reviewed from a modical-bocial viewpoint, and how fow had boon roforred by the medical staff to the Social Service Dopartment. All pationte were also cleared for information only with the Social Service Exchange. 2

${ }^{2}$ Cf. appendix IV on registration of prematurely discherged
patients. 
The medical literature was searched for information regarding similar studies of premature discharge or of desirable hospital stay according to cortain diagnoses, but little information could be obtainod. The New York City study, made by its Wolfare Council in 1933-1943, ${ }^{3}$ was the only study of hospital discharges that could be found for comparison with the experience of Louisville General Hospital. This New York study included all patients discharged from all types of hospitals--voluntary, non-voluntary or public hospitals--for all typos of diagnoees in 1933. The monthly statistics of General Hospitel for routine and premature discharges were studied and compared, and tronds were analyzed. These will be presented in the body of the study. These figures include ouch factors as statistics on admissions, deaths, total care during the month, daily average bed ugage during the months under study. The poriod of July 1946 through April 1947 was used and was compared with a bese war year of 1945-1946 and a pre-war year of 1940 .

In the next chapter eection the problems of curtailment and of premature discherge will be discussed. In the succeeding chapters the statistical data of the study will bo presented to show what promature discharge and curtailmont has moant to a sample group of patient s seeking surgleal treatmont at General Hospital.

\section{HISTORY OF CURTATHCHNT IN HEALTH DBPARTIBAT}

The problems of public hospital administration, as of public

${ }^{3}$ Cf. Welfare Council of New York, Hospital Discharge Study, 1943. 
health and nursing programs, are made more complex by responsibility to the public. The responsibility is primarily to give medical service, rather than to engage in research, teaching of medical students, technicians, modtcal social workers, or nurses. No matter how laudable these secondary functions of the public hospital my be, and how necessary they may have becone in performing the first service, provision of medicel care to the community, these secondery functions are not always considered essential by the taxpayer, or the appropriator of public funds. The pubIic hoopital is not designed to make a profit, but more often operates on a deficit, and is therefore handicapped in giving the best hospital care to ite patients.

In recont years in both public and private fields, hospital administration has becose a specific technique with certain aims of a professional nature. This is shown by several very important studies in the field ${ }^{4}$ and by the derelopment of the American Hospital Association and the group of hospital administrators who have had special training for their jobs. In 1922 the Rockefeller Foundation published the following statement on principles of public and private hospital administration. It is quoted by Dr. Franz Goldmann in his excellent atudy of Principles and Problems of Public Yodical Care, 5 Dr. Goldmann's work in this field is notable, as ho knows not only American, but British and continental.

4yalcolm Yac Fachorn, H. D., Hospital Organization and Yanaganent, (2nd rdition, 1946, Physicians Rocord Company, Chicago, Ilinois.)

${ }^{5}$ Tranz Goldmann, U. D., Principlos and Problems of Public Modicel Care, (Columbia University Press, New York, 1945, p. 6. 
experience in this field of public medical adminietration. The Rockor

feller statement gires this definition of a hospital.

$\triangle$ hospital is a comunity organization which provides facilities and personnel for rendering the bighest possible grade of health service to the community, its patients, and to professional groups 3 for educating the community to demend and oupport adequately hoalth services and sound health policies, for oducating additional personnel and professional groups in technical fields in cooperative endearor, and for advancing our knowledge of disease, and its prevention through technical research and appropriate organizations.

Dr. Goldmann also cited the standards for public hospital care which were enunciated by the American Public Wolfare Association in 1939, in a pamphlet ontitlod Ifseontials of Tax-Supported Yodical Services. 6

1. Scope and amount of care sufficient to include all necessary prem rentive and curative service required by persons unable to prow cure it for themselves.

2. Good quality of service and of personal attention.

3. Reasonable accessibility and promptness of service.

4. Continuous care of the patient including

a. Continuity of diagnosis and treatment by different types of service-home, ambulatory-clinic, and hospital or custodial care.

b. Continuity of preventive and curative service.

c. Integration of medical and social treatment.

5. Provisions of service under conditions which will encourage its full use, aroidence of conditions which will deter the needy from securing neceseary medical care or discourage practitioners.

Just how well able the Louisville and Jefferson County Board of Health was to offer the eitizens of the community such public medicel service under the premcurtailment conditions, and under the curtailment policy itself, will now be discussed.

The Board of Health was formed by a merger of the city and county health departaents on March 15, 1942. Since that time health sorvices to the metropolitan area improved. There was an expansion of public 
health nursing services, both in clinies, and in bodside nursing. The former City Hospital beceme known as Louisvillo General Hospital and accopted county patients; simultaneously the administration of the hospital became coordinated with that of the tuberculosis sanitorium, Waverly Hills. Public health services also included commuicable disease control, medical and dental service in the public schools, and the "city doctor" service to indigent persons in their homes, in cases of emergency or extreme hardship. A vory important division in the Health Department's Preventive Division was the sanitation department. Although there is a relationship botween health services offered under each of these divisions of the Board of Health, the scope of this study includes only General Hospital.

The curtailment was to affect ali functions of the combined city and county health department. The Preventive Division also includes meat and milk inspection for the whole metropolitan area, and inspection of some 3,500 food-handling establishments, including restaurants, groceries and tarerns; ${ }^{7}$ communicable disease control, including tuberculosis and renereal disease; and health oxaminations in cormercial buildings. 8 then city doctor service, public health clinics and school and home nursing functions are added to the abore list of functions of the Health Departmont it can be seon what a large undortaking the hoalth organization of a large urban-rural area becomes. It should be kept in mind that all of

7 Idward Edstrom, Gourier-Journal, (January 12, 1947), Section 3, p. 1 . ${ }^{8}$ Ibia. 
these functions are added to the administration of Warerly Hills and General Hospital.

These services call for a large expenditure of money, and curtailment became necessary because of budgeting for the entire health department. The Health, Board has approximately 1,000 employees 9 and an annual operating budget of a little less than $\$ 2,000,000$.

Reasons for the curtailment vere the rising costs of maintenance of the various services, the decrease in the budget appropriations by the tax-appropriating bodies of city and county governments in 1946 for the coming year, and the difficulties in maintaining services because of the scarcity of personnel, perticularly in the nursing profession.

Costs of maintenance of the physical plants, of food for patients and staffs and of salaries of all personnel were all higher in 1945-1946 than ever before, and continued to rise. The Health Depertment wes further handicapped by inheriting deficiont equipment fron pest adminietrations before the merger in 1942, and because it had no replacement account, depreciation of equipment could not be budgeted except by specific appropriations. The department has not been able to meet competition from industry for personnel.

Nursing service is 80 important to any medical institution that it often becomes the focus of the question of adequate care for any individual group of patients. This is especially true in a public teaching hospital, where, because of the financial inability of the patients to buy

${ }^{9}$ Ibid. 
nursing sorvice, all nursing service aust bo paid by salary appropriations for the hospital, or be unpaid student work. The accopted United States average of nursing care per patient per day is three bours, while Goneral Hospital in 1945-1946 was able to furnish only six-tenths of an hour of nursing sorvice por pationt day. It was recognized by the Board that this situation would have to be improved. In 1946-1947, under the plan inaugurated in July 1946, the available nursing staff was so placed on the warde at General Hospital that one and one-half hours per patient per day could be giren, rather than six-tenths of an hour. ${ }^{10}$ It can be soen that Goneral Hospital is still bohind the national average, but is making good improvemont in nursing care under curtailmont.

The Board of Health wishod to provide the best service possible for the citisens. In 1946 it requested a budget of $\$ 2,300,000$ of which only $\$ 1,735,000$ was allored by tax-appropriating bodies of the eity and county. With anticipated revenues of $\$ 150,000$ from part-pay patients, otc., the sum of $\$ 1,885,000$ only equalled the budget for the year $1945 .^{11}$ H Owever, unexpocted revome for the Hoalth Dopartment was added from revenu from real ostate through increased tax-assossmonts, and Municipel Bridge Tunds are expected to add more reveaue. Tho totel from those sources would only be $\$ 142,000$ for the year 1946-1947, onding July 1, 1947.12 othor rerenue from drug seles, foes and from dairies in adjacent

10 yinutes of the Board of Health, Louisvillo and Jefforson County, July 1946, "Curtailment in Health Service," p. 2.

11 Ibid.

${ }^{12}$ Edstrom, 10e. cit., p. 1. 
11

counties for food inspection might add another $\$ 150,000$ to the total budget of the Health Department. The Health Board had hoped to spend $\$ 175,000$ alone on repairs for General Hoopital kitchens, so it can be seen what large expenditures are noeded.

Wen the Board asked for $\$ 2,300,000$ and got $\$ 415,000$ less than they requested, they thought it necessary to retrench health services, and to curtail the program in all phases. It is with General Hospital that this paper will deal. In asking for the above budget, the Board maintainod that it was moeting only minimum noeds of the community. With a large slice of the requested budget not granted, measures for curteilment were in order. The department had hoped to provide a "semisatisfactory health program for the city and county, "13 through the budget originally requested for 1946-1947, but made the decision to curtail after the appropriations failed to pass.

In making the decision to curtail service, the statement was made by the Board of Health that "no attempt has been made, nor can be made, to meet even a conservative and moderate estimate of the medical needs of the community. The restriction of funds forced this curtailment. .... To do otherwise (than to curtail service) would mean complete breakdown of all health activitios because of the steoply rising costs."14

The Board decided that the cltizens would get better medical service if the work were curtailed than if the reduced budget were made to

13 Minutes of Health Board, op. c1t., p.2.

14 Ibid. , p. 3 . 
spread over a largor area of sorvice. There was a choice between lowering the standards of quality of modical service, or of discontinuing or restricting certain services, i. e., reducing the quantity of medical service available to the public. The Board of Health felt that econonios necessitated by the reduced budget and by increased costs of oporation could only be made by actually restricting ward service at General Hospital and Vaverly, as well as cutting out wuch of the work of the Preventive Division. The Board knew curtailmont of ward service would restrict the use of General Hospital as a teaching facillty by the University of Louleville Modical School. 15 The Modical School has developed Nichols General Hospital, a Veterans diministration facility located in Louisville, as a teaching placoment for studonts. 16

The ourtailmont involved all branches of the Board's work. Waver1y Hills" bed capacity was cut from 452 in 1945-1946 to 400 for $1946-1947$. Service vas noeded for 480 patients. 17 The curtailmont of sorvice to tuberculosis pationts was made in spite of the increased noed for tubercu108is case-finding, especially in the Negro population. More patients were kept longer on the waiting list for admission to wavorly Hills, and in many cases patients had to be discharged prior to arrest or ouro of the disease. Before the date of this study a change was recomnended by Grand Jury which asked that an additional $\$ 50,000$ be allotted to waverly

${ }^{25}$ Ibid., p. 4.

16 Letter to investigator. Irom Dean John waIker noore.

${ }^{17}$ Yinutes of Health Board, op. cit., p. 2. 
Hills to reopen the wards wore up to 60 beds were unoccupled due to shortage of funds, and to purchase long-needed equipment. ${ }^{18}$ Howerer, the Board of Health took no action in this matter in Fobruary on this reoCanondation of the December Grand Jury.

The Prerentive Vivision was also affected by the general cut in funds, making roduction of service nocessary. Perhaps this dirision's 1088 was greater in proportion to its varioty of functions than that of tho two hospitals. It lost sanitation inspectors, and public health nurses, city doctors and had to curtail its public school medical and dental programo. This affected the sane group of patients sorved by Goneral Hospital.

General Hospital is a most important service to the community and in many ways represents the Health Department to its patients. Its Bervice was seriously curtailed in July 1946. With the requested budget of $\$ 2,150,000$ from City and County funds, plus tho hospital's own revonue (cf, supre, p. 10) the Board had hoped to be ablo to protide in 1946-1947 for an average of 400 bed patients por day and for an average of 500 pationte por day in clinics. 19

Onder curtailnent it was possible to maintain clinic service at about the desired level. An arerage botween 400 and 500 patients per day will be served in the various clinics. It was also possible to maintain. ${ }^{18}$ Courier-Journal, News article, (February 20, 1947) Section 4, p. 1.

19 yinutes of the Health Board, op. cit., p. 1. 
the twenty-four hour service of the energency clinic. ${ }^{20}$ It was estimated that the elimination of city doctor service would make heavier demands upon the corgency clinic. Curtailment of the number of bed patiente may add to the clinic those patients whose treatment cannot be completed on the wards. A certain amount of this typo of sorvice is always necossary In a municipal or any public hospital with clinic facilitios, as it saves bod space and makes for more economical service. However, after curtailment modical patients were treated alnost wholly in clinic, bocause tho medical and surgicel vards were combined. Therefore, clinical work-nps and diagnosis in clinic rather than on the ward becase more frequently the practice.

The inpatient group at Goneral Hospital has had to bear tho brunt of the curtailment of service in order to reduce the daily arorage of beds occupied from 400 (the requested number) to $3100^{21}$ The actual averages during 1945-1946 were between 350 and 450 patients, or a general arerage of 385 bed patients per day on all wards of the hospital. ${ }^{22}$ According to hospital administration and public health experts, a reliable formule of number of hospital beds per population has been determined. Various ourveys of Loufsville's hospital sorvice have been made in the past, and Dr. A. C. Bachwejer's recent ourrey indicated that at least 600 beds should be provided for acute hospital patients in public facilities

20

Ioid., p. 2.

21 Ibid.

22

Ibid. 
in a community the oize of Louisville, 23

The Board of Health feared that curtailment of ward service would mean that patiente eligible for public modical care at Goneral Hospital would not be able to obtain free service, and their conditione might go untreated. This study does not make any study of the patients it was not possible to treat. This is, in fact, one of the reasons for the premature discharge plan; the noed to give service to a large number of patients on restricted facilitios.

Curtailment meant first that fewer patients could be servod on the wards. The daily bed arorage by months since July 1946 has actually slipped below the estimated figure of 310 hospital beds in daily use, to a general arerage for six months through January 1947 of 226 bods in deily use.

By action of the Board of Health in Fobruary 1947 the bed capacIty at Genoral Hoopital was increased by 40 bods, thus raising the 310 daily bed usage to possible 350 beds. These bods wore addod to the irards alroady in use, and would remein in use until July 1947, the end of the fiscal year. The $\$ 15,000$ it 1s estimated that it cost the hospital to open these 40 beds was to come from "unallocated funds" and savings from other Health Board activities. 24

The curtailment of ward services called for a roorganization of beds on the wards of General Hospital. It was docided in June 1946 to

\section{Ibid.}

${ }^{24}$ Courier-Journal, Newe article, (Fobruary 20, 1947, p. 1. 
close five of the wards 3 three adult medical vards, which were combinod with the surgical warde, one pediatric ward, and one obstetrical ward. 25 This has meant that the number of beds loft for acute disease treatment in the adult age group was cut to 150 bods for white and Negro patients. Further results of curtailment to the surgicel service will be considered in more detail later.

The last important aspect of curtailment of services of the Louieville and Jefferson County Heelth Department is the effoct on the chronic disease problem. There is now no care offered to chronically ill persons, except custodial care in the over-crowded and ill-equipped almshouse, the Home for the Aged and Infirm, at Shively, Kentucky. ${ }^{26}$ Hedical care in clinles at General will continue, but patients with these longterm illnesses which are often progressively disabling will no longer receive treatment on the warda.

\section{THE POLICY OF PRIALIURT DISGHARGE}

The cost of curtailment to the individual patient is illustrated by the group of petients who here had to be prematurely discharged against bost medical opinion before their ward treatment was reasonably complete.

The reasons for wheh a policy were the same as those leading the Board to decide to curtail all services of the Health Department. They

\section{5 tinutes of the Board of Health, loc. cit., p. 2 .}

${ }^{26}$ Irving Lipetz, "The Louisville Kentucky Home for the Age and Infirm," (Unpublishod master's thosis, Kent School of Social Hork, Univerity of Louisville, 1942). 
are specifically the lack of nursing oorvice in Goneral Hoopital, the lack of space on the wards, which have beon combined from services which used to have separate wards, and the desire to make a quick turnorer of bed space, so that more patients may be served by the number of bede available. Premature discharge helps to accomplish these ends. Some patients have been sent home by hospital ambulance late at night in order to racate a bed which was badly noeded for another patient.

Since July 1, 1946, the total number of premature discharger has been a little less than that of thoee routinely discharged. of a total of 4,846 discharges in the first six months after curtallment was announced, excluding 359 deaths, there were 2,129 premature discharges and 2,717 routine discharges. The cumulative totels for premature discharges and routine discharges through May 6, 1947, are shown in Appendix II, Table 1. Brcluding deaths, these discharger accounted for 2,986 patients premeturely discharged and 4,102 patiente routinely discharged.

In the first period from July through september 6, 1946, the average stay in hospital por patient promaturely discharged was 7.3 days, while the average hospital stay per patient routinely discharged was 10.9 days. The period from January 7 through Fobruary 6,1947 , showed the lowest number of premature discharges, 280, as against the highest number of routine dischargee, 481 ; however, the total discharges showed the 10vest totel in four months. The table of figures on premature discharge and routine discharge during this six-month period will show more graphically the extent and development of tho policy of discharging patients prematurely. This table is found in Appondix II, Table 2. 
The largest group of the promaturely discharged pationts wero mothers and new-born bebies. Surgery service had the next largest number of patiente discharged in this way. Pediatrics service also had some premature discharges.

Curtailment has had specific effects upon the surgical service. The first result is the combination of three of the former medical varde with the corresponding surgical wards; thus, femele surgical colored ward absorbod fomale modical colored. The male medical white ward has beon continued separately from the male surgical white ward. There is a combined obstetrical ward for white and colored patients, and a predominantIy colorod baby ward, an isolation ward and two psychiatric wards, in addition to the four aurgical wards under conolderation in this study.

Curtailmont of ward service has meant that an especially heary load has been placed on the surgery service, which now has 30 beds on Male Surgicel hite, 15 on Male Surgical Colored, 15 on Femele Surgical White, and 15 on Femele Surgical Colored.

This shortage of beds means that the turnover per bed is great, as shown by the total arerage lengths of stay to be presonted later. The hospital is now thought to be operated at too near tho capacity peak. For the best treatment of the individual or for purposes of good teaching practice, a hospitel should probably koep about 25 per cont of the beds racant at a given time, so as to be able to admit some patients on an elective basis. Corteinly the nursing and modical staff works at peak officiency only when not harassed by lack of bods for acutely 111 patients. 
Besides shortage of beds, and great turnover of patients, the surgery service has had to abandon elective surgery almost entirely. The only exception consists of the ten beds that are reserved for hysteroctomies. Flective petients who might before have been expected to have prompt or slightly delayed operations for fibroid tumors, gall bladder, chronic appendicitis, herniorrhaphy, or orthopedic conditions, must do without an operation until such time as they may become emergencies. Most admissions are either emergency surgical conditions or the results of accidental injury, such as stabbings, gunshot wounds, automobilo accidents, train wrecks, etc. The work on surgery has, therefore, taken on an emergency nature, which is contrary to good surgical practice, and to the proper teaching of surgery to medical students and internes. The work of the surgical department has become ameliorative and ofton curative, but the preventive aspects of its work are 10st. The hope of Dr. Arnold Griswold, chief of surgery, for a surgery service combining the principles of psychiatry for the upset patient facing or recovering from major aurgery must be postponed, perhaps indefinitely.

In this respect ourgery service is like the rest of General Hospital, and Ilke Waverly Hills, and the Preventive Division; in not boing able to offer anything but energency service to the citizens of the city and county who are medically indigent.

Yedical treatment is sometimes delayed by the pationt in the hope that he will cure himself with home remedies or that his private doctor can effect a cure. But when the clinic setup is overcrowded and the doctors are overworked thore, as woll as in the wards, medical diagnosis and 
treatment is bound to be slower. This delay may cause prolongation of illness, and occasionally further complications, with increased cost to the patient.

Sometimes the best diagnostician purposely g0es slowly in decidIng from his observation of the patient, and analysis of data, just what tho diagnosis is, and under what circumstances medical social treatment will be most effective.

Prognosis cannot usually be estimated until treatment is bogun and observed. The doctor who knows his patient, his habits, and previous medical history is safor than the one who doesn't know these factors in making a statement regarding the patient's future, just as he is safer in diagnosing the trouble in the first place. The basis of modicine being psychoscmatic, it is more important than over that the physician and surgeon know his patient as a person. While this is well recognized in theory by this generation of young doctors and by their instructors, it cannot always be practiced in over-loaded clinics or on warde where turnover is high.

A teaching hoopital that falls into the older philosophy of treating the disease rather than the patient with a disesse, or the pationt with a disability or a health problem, is doing incalcuable harm to its students, its internes and resident staff, as well as its visiting staff men. This 2088 is quite heary also whon the resultant lack of care to the individual petient is considered. Bffectiveness of medicel care is known to rest with tho cooperation of the petient with his doctor and nurse. Won this is not sought by the professional staff, care can 
21

become wasteful, rathor than helpful to the patient, and, therefore, wasteful also to the community. 


\section{GHAPTFR II}

\section{COMPARISON OF ONE HUNDRTE PRAM MATURHLY DISGHARGED PATIMNTS WITH ONE HUNDRBD ROUTIIELY DISGHARGED PATIFWTS}

AT LOUISVILLE GENBRAL HOSPITAL

'In this chapter the control and atudy groups of patients discharged under the policy of curtailment of ward service at General Hoepital will be compared. The primary focus of the study is on objective measures of service to the patient groups, such as length of hospital stay, type of medical or surgical care receired, condition at discharge, frequency of readmissions, and frequency and extent of clinic attendance. These factors have a bearing upon the recovery of any surgical pationt, and are factors which can be compared statisticelly although they are not subject to corrolation with results of modical care in so small a study group.

The patients in both study and control groups were from the white and Negro surgical wards caring for both oxes. Table 1 gives the sex and color distribution of the study group of 100 prematurely discharged patients and of the control group of 100 routinely discharged patients. Both these groups of petients were cared for on the wards and discharged from the hospitel at the same time, during July and August of 1946, immediately after curtailment went into offect. The race and $s e x$ 
TABLIR 1 .

RACE AND SEX OF ONE HWNDRED PATIANTS OF LOUISVILLE GRNERAT HOSPITAL SURGICAL TARDS PREMATURRIY DISCHARGIM DURTIG JULI AND AUGUST 1946 COMPARRD VITH ONE HUUDRFD PATIFNTS DISCHARGTED ROUTINAHY IN SAMT PIRTIOD

\begin{tabular}{|c|c|c|c|c|c|c|c|}
\hline \multicolumn{4}{|c|}{ Prematurely Dibcharged } & \multicolumn{4}{|c|}{ Routinely Discharged } \\
\hline Rece & & & & Race & & & \\
\hline & Total & Yole & Pcale & & Total & Melo & Fomale \\
\hline Totel & 100 & 60 & 40 & Total & 100 & 46 & 54 \\
\hline Whito & 58 & 42 & 16 & White & 52 & 21 & 31 \\
\hline Negre & 42 & 18 & 24 & Negro & 48 & 25 & 23 \\
\hline
\end{tabular}

distribution is similar for the two groups although thore are minor differences.

It should be noticed in Tablo 1 that there are more males in the prematurely discherged group and more females in the routinely discharged group. When sex and race are considered together it can be soen that the Negro patients routinely were more equally distributed between male and female wards than was true of the prematurely discharged patients. Conversely for the white group of prematurely discharged patients there were a majority of males over females, with the femeles having a preponderance of routinely discharged patients. Reasons for these differences will be shown in the anelysis of the length of stay per diagnosis.

The color distribution is quite sinilar for the control and the study groups although it is more nearly equal in the routinely discharged group, especially as between the sexes. Color distribution is not significant in the comparison of the group. As will be shown later the 
diagnosis, which determined the average length of hospital care required, as well as the extent of clinic attendance, was much more important in determining premature discharge than any factor of sex or of color.

TABLF 2

AGR DISTRIBUTION OF ONE HUNDRIAD FREMATURELY DISGHARGED PATIFNTS AND OF ONS HUNDRED ROUTINELY DISCHARGED PATIFNTS

TROM LOUISVIILE GENERAL HOSPITAL IN JULY 1946

\begin{tabular}{|c|c|c|}
\hline Axe & Promaturely Discharged & Rout inely Discharged \\
\hline Under 21 yeare & 18 & 16 \\
\hline 21 under 41 years & 36 & 39 \\
\hline 41 under 61 years & 27 & 27 \\
\hline 61 under 81 years & 15 & 16 \\
\hline Orer 81 years & 4 & 2 \\
\hline
\end{tabular}

Table 2 above shows that oightoen of the one hundred prematurely discharged patients and sixteen of the one hundred routinely disoharged patients were children or adolescents below the age of twenty years. Curtailmont of podiatric ward service made occasional admisaions of children under fourteon years of age necessary in energency surgical cases, as only four white pediatric beds were left after July $11,1946$.

In the prematurely discharged group an almost equal number of patients, nineteon in all, appeared in ages beyond sixty years; whereas eighteen of those patients routinely discharged fell in these age interrals. The exact figures for the study and control groups may be seon in the accompanying Figure $I$ on age distribution. Here it can be soen that 


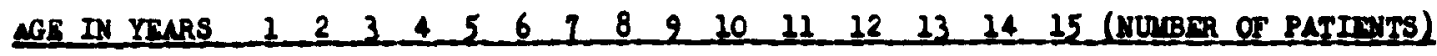

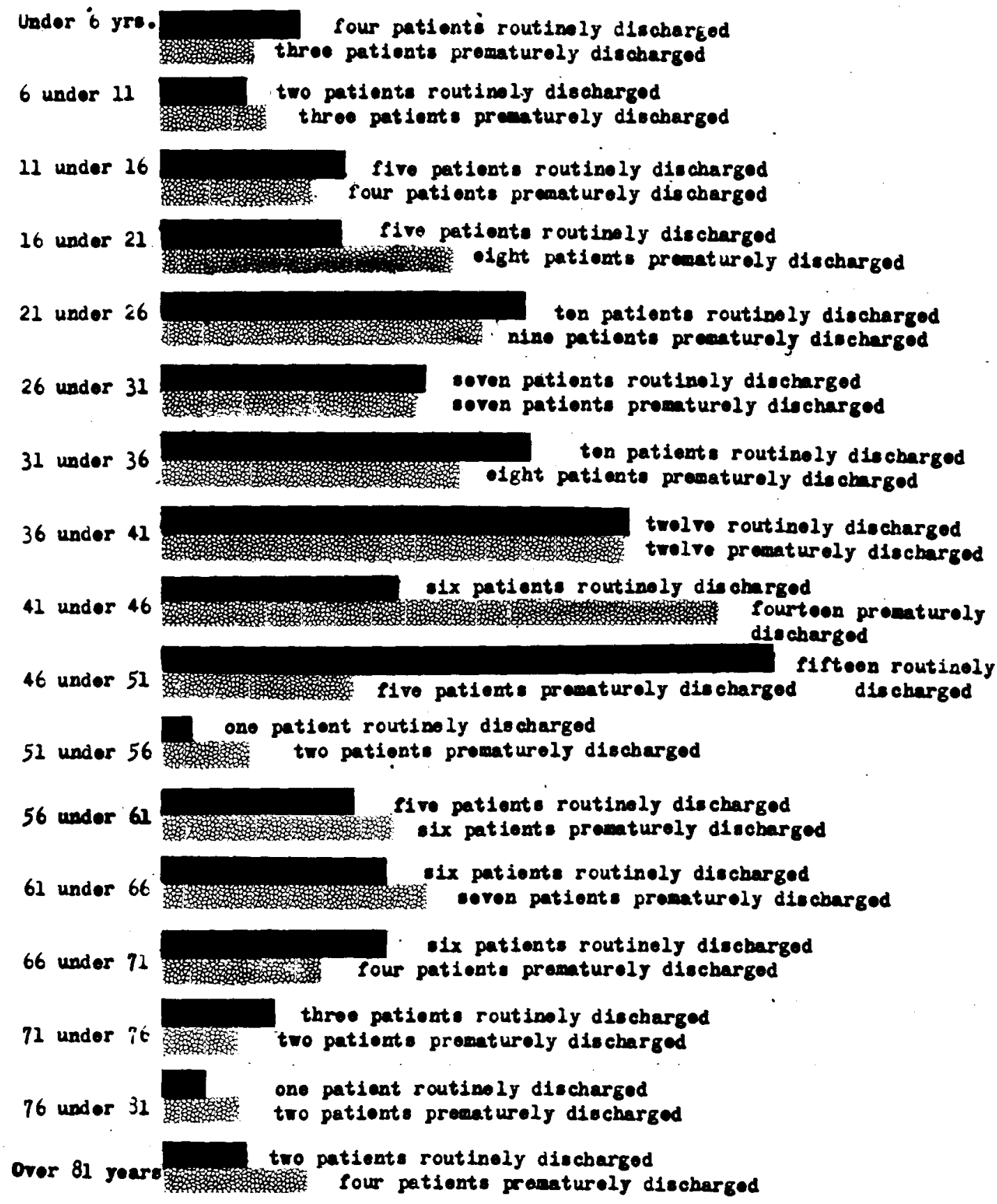

Mg. 1.--One hundred prenaturely discbarged patients conpared with ane bundred routinely discherged patiente fron Louierille General Hospital in July 1946 by age distribution. 
the groups were roughly similar in age distribution. There were fow old people, compared to the large group in both study and control groups who were of mature, productive years. Almost equal numbers, sixty-three prematurely discharged pationts and sixty-six routinely discharged patients, fell between the ages of twenty-one and sixty years, the age of greatest pcononic productivity.

The fact that there wore so fow patients over sixty-five years of he may be explained by the fact that we are studying patients of an acute surgical service. Persons in this ago group aro less likely to suffer from diseases requiring surgical treatment, on an emergency basis. Most of them require treatment for chronic diseases which is more frequently given on the modical wards. This was oven more true during curtailment. Actually, because of the curtailment of modical service on medicine to a minimum, chronic disease sufferers cannot be treated at Louisville General Hospital in any abstantial numbers.

However, some of the surgical patients studied were chronically

111 persons hospitalized for treatment of an exacerbation of a chronic condition, or for an acute illness or accident not associated with the chronic disease. Primarily, however, the patients in our groups were active, young and middle-aged persons, suffering from acute illness or from accidental injuriea.

The age of pationts becomes important under some circumstances. pisability due to accident, or following an operation, becomes a very much more serious problem to the men between twenty and oixty years of age who have a family to support, than it is to a young child whose 
support is assured whother he is ill or not. The single man over sixty, who is employed, is also greatly handicapped by illness. However, for the most part, the men in the study group of prematurely discharged patients over sixty-five years of age were not gainfully employed. Many of the older women, likewise, were no longer in the labor market, being provided for by rolatives, sarings, insurance, or relief funds from the community.

It is the younger women, for: whom illness means 108 of working time in the home, or in outside employment, that auffer most from acute illness. For them the number of days spent in bed is crucial. It may mean the $108 s$ of a job, going into debt, or letting the house and ohildron suffer for lack of care and oupervision.

For such group of mature, productive poople an acute or chronic illness, requiring oron a short hospitalisation and an extended period of convalescence at home after discharge, is a catastrophe. The members of this group are frequently sole wage-earners for a family, and are most seriously handicepped if illness becomes permanent disability, or a chronic disturbance of general health and physical or omotionel efficieny.

STATISTICS ON LRANGTH OF HOSPITAL STAY FOR STUDY AND CONTROL GROUPS

The hypothesis on which this study of premature discharges was undertaken was that curtailment made cortain differences in the treatment of patients at General Hospital, after July 1946, and that these differonces could best be illustrated by the service rendered the patients who Fere selocted by the doctors for premature discharge. Therefore, a 
comparison of length of hospital stay was made for the study and control groups as a whole, first; then by ward divisions; then by presence or absence of an operation or actual surgical intervention of any kind; and finally by special services and individual diagnoses.

For the four surgical wards, white and colored, male and female, 1t was found that one hundred patients prematurely discharged had totalled 1,055 days of hospital care, an arerage of about ten and one-half days per patient. This includes the ontire one hundred patients. In this group there were several patients who were discharged before they should have been in the opinion of the doctor, but who remained in the hospitel wards, principally because they had no home or comanity resource in which to spend their convalescence. When these persons are excluded from the count, the general average for all prematurely discharged patients was found to be almost nine days. I

The one hundred routinely discharged patients stayed a total of 1,264 days or an average of almost twelve and two-thirds days. However, when the unusual case in this group is discarded ${ }^{2}$ the average becomes just a little over eleven hospital days for ninety-nine routine discharges.

IThese patient s were older than the average age for prematurely discharged group, and suffered with complicated illness, prostatectony, with acute urinary retention and oxtravesation (a complication which requires extended care and bedside nureing); cholecystectomy, complicated by food retention difficulties which could not be managed at home; gastrostony following lye poisoning to throat, stomach and mouth, and which later necessitated rib resection; and a radical mastectomy for carcinoma of the breast.

2 This patient stayed 165 days for diabotes, otitis and a degenerative condition of the liver, before his routine discharge. 
In considering these arerage lengths of hospital stay it should be noted that there rere in the routinely discharged group (as in the prematurely discharged group) a great many patients who stayed two days or 1088, and yet were discharged according to medical advice, their hospitel treatment considered at an end. Therefore, a majority of patients stayed less than five days, whother their discharge was considered by the medical staff premature or routine. For instance, fifty-nine of the routinely discharged patients stayed less than five days, while forty-three of the prematurely discharged patients stayed 108 than five days in the hospital for thoir original admission.

Tables 3 and 4 show the length of hospital stay for certain special services, for the prematurely and routinely discharged groups under consideration. They show that in general the larger groups of patiente fram either group who atayed under five days were those on the generel surgery service. Proportionate groups in study and control groups stayed relatively short stays on orthopedic sorvice, with a few more hospitalizetions between eleven and fifteen days for the prematurely discharged group than for the routinely discharged group, contrary to expectation. There is a considerable difference in the stay of the several eye patients and general modical service patients in the study and control groups; thero are more longer etays in the routinely discharged groups than in the prematurely discharged groups. Genito-urinary pationts stayed for longer stays in the prematurely discharged than in the routinely discharged group. It was the gynecology service which showed the greatest difference in length of original stay. The stays were longer in the prematurely 
TABLE 3

LWAGTH OF HOSPITAL STAY FOR ONG HUNDRE PATIKNTS PREYATURALY DISGHARGED FROM LOUISVILIS GMNBRAL HOSF ITAL, JULY 1946, ACCORDING TO SPBCIAL SUFGICAL SEAVICE

\begin{tabular}{|c|c|c|c|c|c|c|c|c|}
\hline vaye stay & $\begin{array}{l}\text { Num } \\
\text { Gon. } \\
\text { Surgse }\end{array}$ & $\begin{array}{l}\text { of Pat } \\
\text { Orthos }\end{array}$ & $\begin{array}{l}\text { ats on } \\
\text { Gran. }\end{array}$ & $\begin{array}{r}\text { Special } \\
\text { Gen. } \\
\text { Yod. }\end{array}$ & $\begin{array}{c}\text { surgical } \\
\text { Bye }\end{array}$ & $\begin{array}{l}\text { Sorvices } \\
\text { Proctol- } \\
\text { osy }\end{array}$ & $\begin{array}{l}\text { Ueaito- } \\
\text { Urinary }\end{array}$ & $\begin{array}{l}\text { Intervel } \\
\text { Totele }\end{array}$ \\
\hline 0 thru 5 daye & 18 & 15 & 3 & 1 & 1 & 4 & 1 & 43 patiente \\
\hline 6 thru 10 days & 9 & 4 & 7 & 2. & 1 & 1 & & 24 pationt: \\
\hline 11 thru 15 days & 4 & 8 & 4 & 1 & & & & 17 pationts \\
\hline 16 thru 20 days & & & 1 & & & & & 1 pationt \\
\hline 21 thru 25 days & 2 & & 2 & & & & & 4 patients \\
\hline 26 thru 30 days & 1 & & & 1 & & & & 2 patients \\
\hline 31 thru 35 days & 1 & & & & & & 1 & 2 patients \\
\hline 36 thru 40 days & & & & & & & 1 & 1 pationt \\
\hline 41 thru 45 daye & & 1 & & & & & 2 & 3 patients \\
\hline 46 thru 50 days & 1 & & & & & & & 1 patient \\
\hline 51 thru 55 day & 1 & & & & & & & 1 pationt \\
\hline 56 thru 60 days & & & & & & & & 0 patient 8 \\
\hline 61 thru 65 days & & 1 & & & & & & 1 patient \\
\hline Total: & $\begin{array}{l}37 \\
\text { pts. }\end{array}$ & $\begin{array}{l}29 \\
\text { pts. }\end{array}$ & $\begin{array}{l}17 \\
\text { pts. }\end{array}$ & $\stackrel{5}{\text { pto }}$ & $\begin{array}{c}2 \\
\text { pts. }\end{array}$ & $\begin{array}{l}5 \\
\text { pts. }\end{array}$ & $\mathrm{pta}^{5}$ & 100 patiente \\
\hline $\begin{array}{l}\text { Total days per } \\
\text { special service }\end{array}$ & $\begin{array}{r}368 \\
\text { days }\end{array}$ & $\begin{array}{r}290 \\
\text { days }\end{array}$ & $\begin{array}{r}175 \\
\text { daye }\end{array}$ & $\begin{array}{l}55 \\
\text { daye }\end{array}$ & $\begin{array}{r}8 \\
\text { days }\end{array}$ & $\begin{array}{r}21 \\
\text { deys }\end{array}$ & $\begin{array}{r}159 \\
\text { daye }\end{array}$ & $\begin{array}{l}1076 \text { days for } \\
100 \text { pationts }\end{array}$ \\
\hline
\end{tabular}


TABLE 4

LWNGTH OF HOSPITAL STAY FOR ONA HUNDRED PATIWNTS ROUTINEY DISCHARGED FROY LOUISVIWW GANEKAL HOSPITAL, JULY 2946, ACCCRDING TC SPECIAL SURGICAL SRRICR

\begin{tabular}{|c|c|c|c|c|c|c|c|c|c|}
\hline Lys Stay & $\begin{array}{l}\text { Gen. } \\
\text { Surge }\end{array}$ & $\begin{array}{l}\text { mber of } \\
\text { Ortho. }\end{array}$ & $\begin{array}{l}\text { tients } \\
\text { Gra. }\end{array}$ & $\begin{array}{l}\text { on Speci } \\
\text { Nouro. }\end{array}$ & $\begin{array}{l}\text { Surg } \\
\text { Gon. } \\
\text { Yod. }\end{array}$ & $\begin{array}{l}\text { ical S } \\
\text { Bye. }\end{array}$ & $\begin{array}{l}\text { ervi ces } \\
\text { Proct. }\end{array}$ & G-U. & $\begin{array}{l}\text { Interval } \\
\text { Totele } \\
\end{array}$ \\
\hline 0 thru 5 days & 32 & 13 & 6 & 2 & 3 & 2 & 1 & & 59 patient: \\
\hline t thru 10 days & 6 & 3 & 5 & 3 & & 1 & & 1 & 19 patients \\
\hline 11 thru 15 days & 2 & 2 & 1 & 1 & & 3 & & & 9 patients \\
\hline 16 thru 20 daye & 1 & & & & & & & & 1 patient \\
\hline 21 thru 25 daye & 1 & & & & . & & & 1 & 2 patients \\
\hline 26 thru 30 days & & & & & & & & 1 & 1 pationt \\
\hline 31 thru 35 days & 1 & 1 & & & 1 & 2 & & & 4 pationts \\
\hline 36 thru 40 daye & 1 & & & & & & & & 1 patient \\
\hline 41 thru 45 deye & 1 & & & . & & & & & 1 patient \\
\hline 46 thru 50 days & & . & & & & & & 2 & 1 pationt \\
\hline 51 thru 55 days & & & & & & & & & 0 patients \\
\hline 56 thru 60 daya & 2 & & & & & & & & 2 pationte \\
\hline 61 thru 65 days & & & & & & & & & 0 petiont. \\
\hline Over 65 daye & & & & & $1 *$ & & & & 1 pat1ent \\
\hline lotelo & $\begin{array}{l}46 \\
\text { pte. }\end{array}$ & $\begin{array}{l}19 \\
\text { pte. }\end{array}$ & $\begin{array}{l}12 \\
\text { pts. }\end{array}$ & $\begin{array}{l}6 \\
\text { pts. }\end{array}$ & $\begin{array}{l}5 \\
\text { pta. }\end{array}$ & $\begin{array}{l}7 \\
\text { pte. }\end{array}$ & $\begin{array}{l}1 \\
\text { pt. }\end{array}$ & 4 & 100 pationts \\
\hline $\begin{array}{l}\text { lotal days per } \\
\text { epecial service }\end{array}$ & $\begin{array}{r}676 \\
\text { deye }\end{array}$ & $\begin{array}{r}102 \\
\text { deys }\end{array}$ & $\begin{array}{r}70 \\
\text { days }\end{array}$ & $\begin{array}{r}27 \\
\text { daye }\end{array}$ & $\begin{array}{r}201 \\
\text { daye d }\end{array}$ & $\begin{array}{r}85 \\
\text { days }\end{array}$ & 4 & $\begin{array}{r}105 \\
\text { deys }\end{array}$ & $\begin{array}{r}1270 \text { daye for } \\
100 \text { patients }\end{array}$ \\
\hline
\end{tabular}

*Inis petient had diebotes, otitio, and a degenerative condition of the lirer, which noceseltated his otaying in tho hospital for 165 daye bofore routino discharge. 
discharged group than in the routinely discharged group of patiente; contrary to expectation, as half of the routinely patients on this service stayed less than five days, as compared with about one-sixth of the prenaturely discherged group of gynecology patients who stayed this short a stay. While half of the routinely discharged gynecology patiente were in the hospital between six and fifteen days, eloven of the seventeen prematurely discharged groups on this service stayed this longth of time, for their original admission, and three nore prematurely discharged patients stayed between sixtoen and twenty-five days. Whon the total number of days is computed for each service it may bo seen that general surgery, eye, general medical patients atayed longer in the routine group, and the other services in the premature group of patients. whon one hundred patients prematurely discharged wero interriewed and their medical records were checked, it was found that twentyfour patients on fomale surgical ward stayed an average of elovon and seren-twelths days. Inis was a longer average than that of the female white group, who stayed eight and three-sixteenths days on the ererage. logether the fenale patients, whether white or colored averaged about ten days. The general male arerege for colored and white pationts was ten. The colored men in the study group stayed seven and one-helf days, and the white men stayed longer, twelve and one-sixth days. The accompanying table shows the relationship of color and 8 ex to length of stay for the study group of prematurely discharged petients.

Before proceeding with an analysis of the length of stay obtaining in study and control groups for certein spocific diagnoses, it is 
Interesting to seo what special services claimed our pationts in both groups. For the purposes of this study the patients were divided into those on general surgery, including many operations, not localized to any portion of the body, and to certain accidental injuries, etc., and illne日s which may be best classified as general surgery. The other specLalities are orthopedics; gynecology; neuro-surgery, involving brain, opinal and other work with nerve centers; eye; proctology; and genitom urinary services. For purposes of clarification of the meaning to the surgical varda of curtailment, another group must be included; the patients admitted to surgery because of overcrowding of tho medical wards who were not in noed of surgery. As they were admitted to surgicel ram ther than to modical service, they became a small part of the study and control groups. Table 5 shows the comparative numbers of patients admitted to each special service of surgery.

From the accompanying Table 5 it is interesting to note that the numbers admitted to those specialties claining the amaller number of patients are roughly similar for the two groupe however discharged. Thus General ledicine clained fire prematurely and five routinely discharged patients, while proctology, genito-urinary and eyo service also claimed vory few pationts from each group. In other words, the same services claimed the greator proportion of both groups of patients. The diagnoses of the two groups of patients are practically identical, whother the patients were discharged prematurely or routinely. Most of gynecologieal petients, for instance, were treated for conditions which necessitated hysterectomies, and the genito-urinary patients were 
TABLE 5

GENERAL HOSPITAL'S SURGICAL SERVICRS ON WHICH ONE HUNDRED PREMATURRLY DISCHARGED PATIEHTS AND ONR HUNDRFD ROUTINELY DISCHLRGED PATIDNTS WERE ADMITTED IN JULY 1946

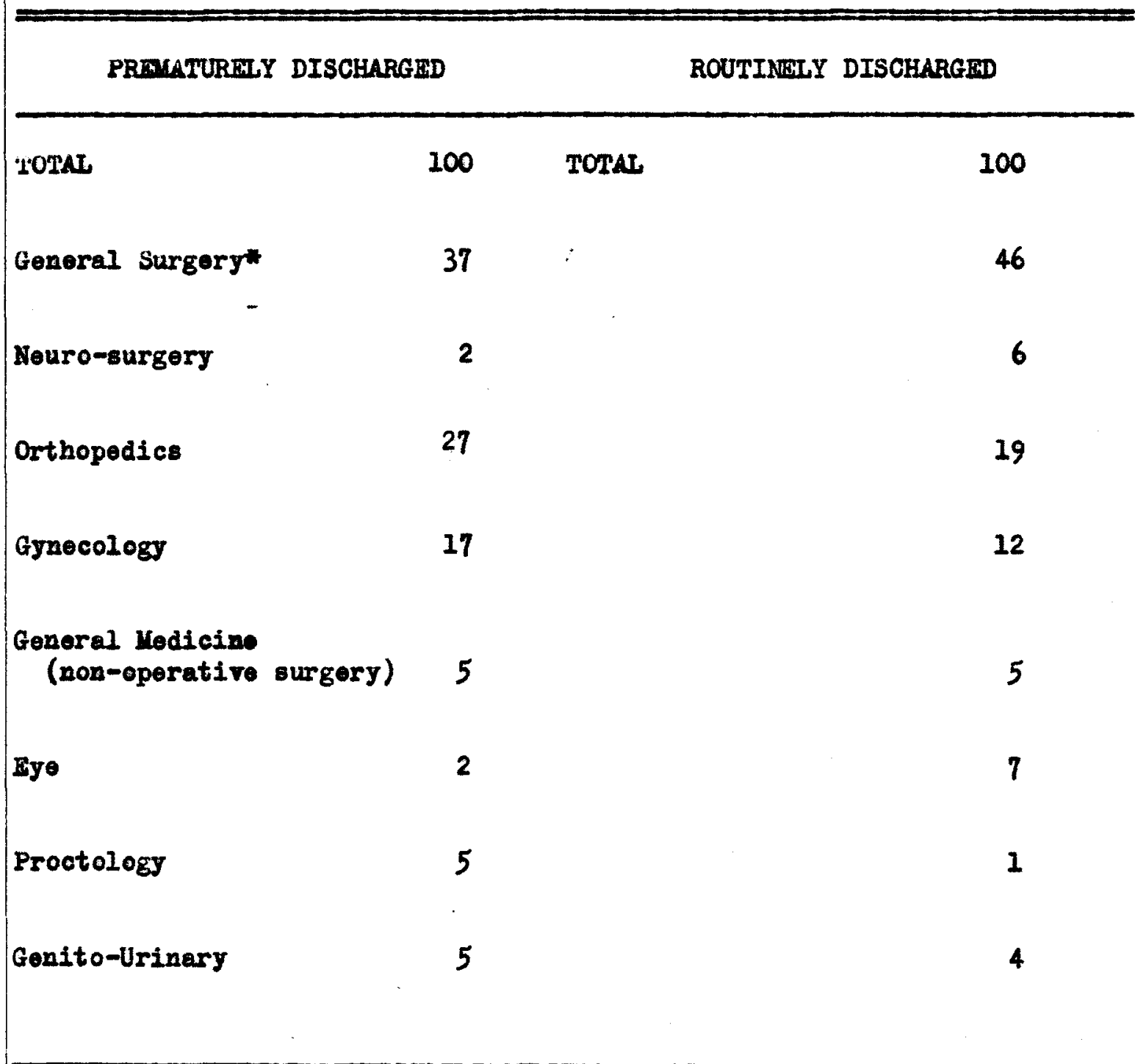

The totals are compiled for incidence of prinary diagnosis. There were several patients with multiplo diagnoses, particularly many of gynocology petients, who were hospitalized for fibroid tumors, salpingitis, ovarian cysts, and who underwent hysterectomies and cauterirations of the corvix.

The incldence of diagnoses can be found in later tables. 
usually in the hospital because of acute urinary retention with extravasetion or prostatectomy with complications. Practically all tho orthopedic patients in both groupe were in the werds because of accidentel fractures, although there were a few cases of osteonyelitis, synorectomy, and capsulotomy in the premeturely discharged group. Neuro-surgery beds were ocoupied by accident cases, usually of childrea, with fracture of akull, suspocted or proven by X-ray studies. General modical patients had a varioty of diagnoses, usually carcinoma, diabetes or some complication of these diseases. In the two groups of patients the portion of thoes on orthow pedice and those on general surgery are reversed for prematurely and routinely discharged groups.

The specialties are allotted a certain number of beds, according to the expected number of patlents per service, and the expected turnover, for such patients. For instance, ten beds are reserved for elective hysterectomies, but other services are not so fortunate. In fect, gynecology is the only service with reserved beds for certein cless of patients. The beds on surgery have to be devoted largely to accidental injuries, es Table 5 shows, and to omergency surgery, which together account for the preponderance in both study and control groups of patients on orthopedice and generel surgery.

Whon diagnoses are considered, it is interesting to note that in the prematurely discharged group trenty-six of twenty-nine patients on orthopedic service were fracture ceses; in the routinely discherged group sixteen of the ninetoen orthopedic patients ouffered fractures. For the prematurely discharged patients the most frequent reason for their 


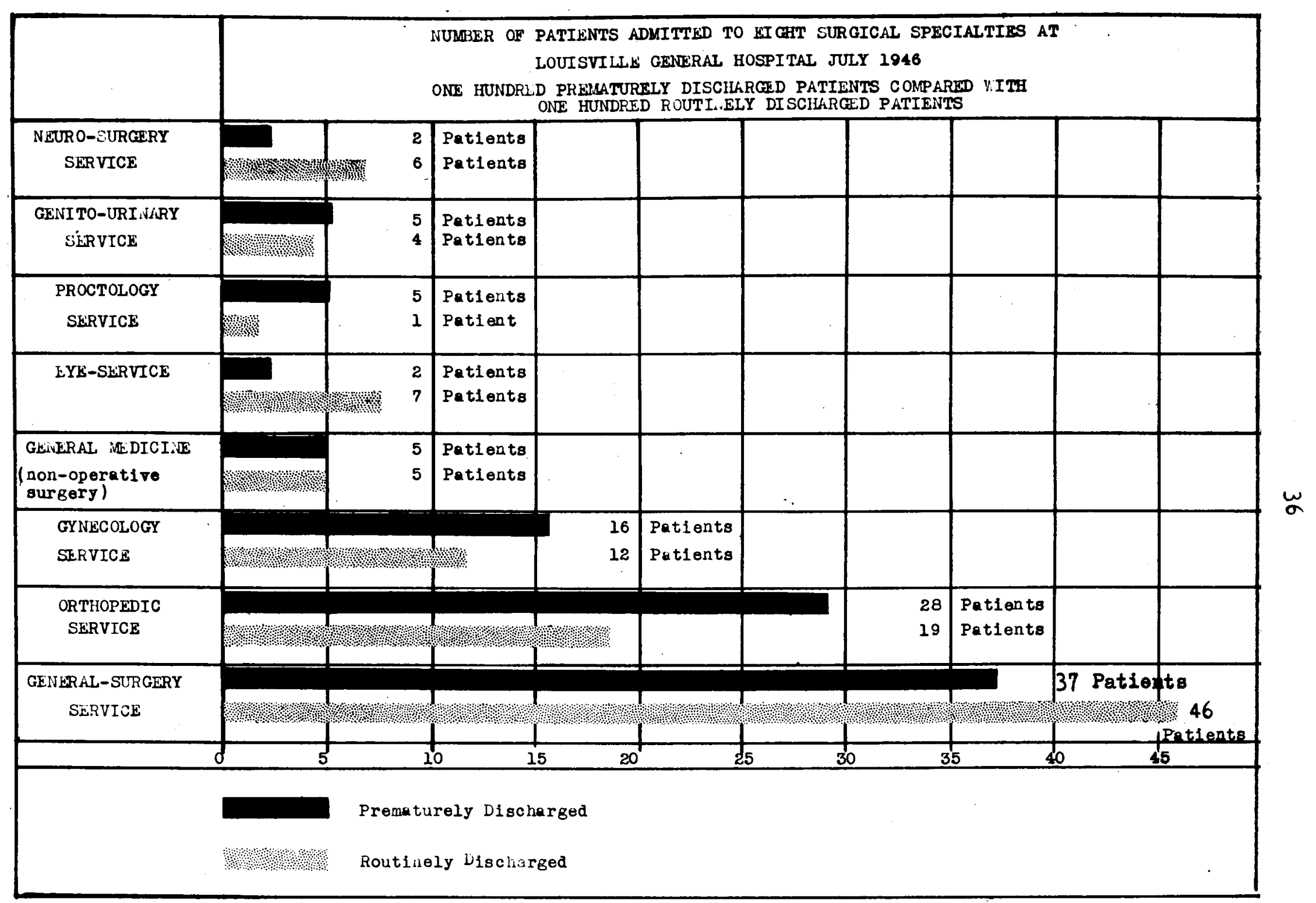

Fig. 2.- Comparison of prematurely and routinely discharged patients by number of patients admitted to surgical services at Louisvillo Generel Hospital, July 1946. 


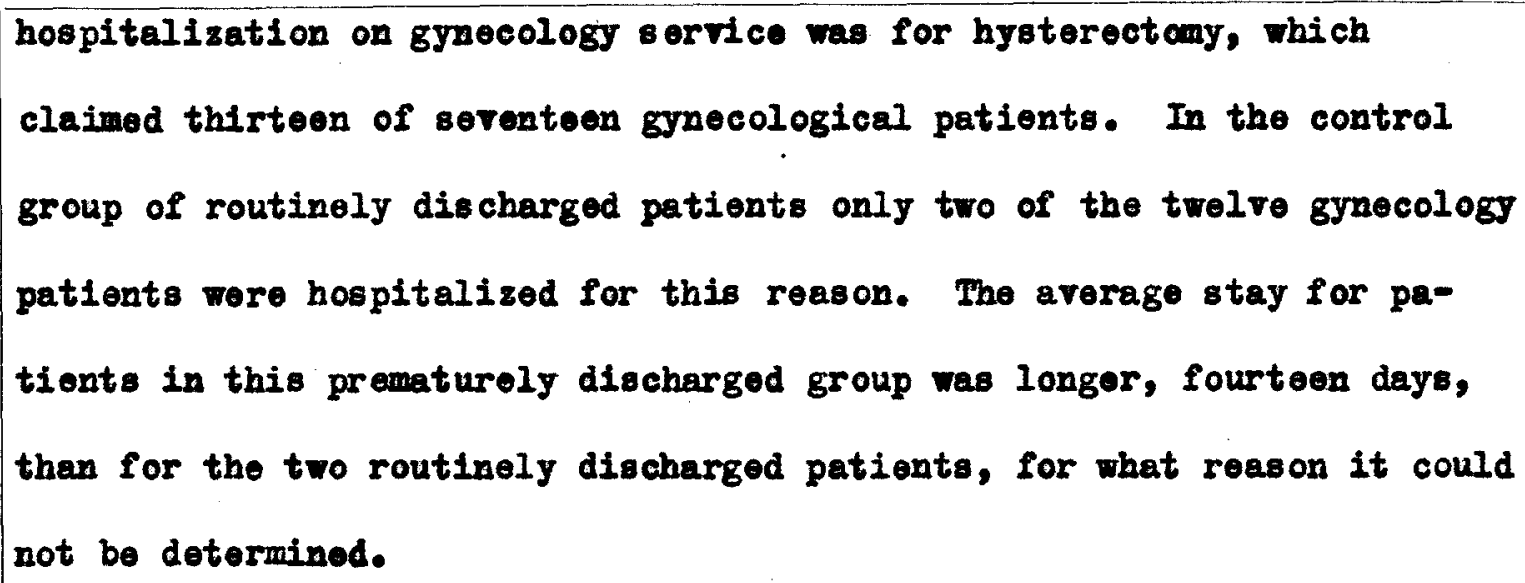

In the dirlaion of general surgery the prematurely discharged patients with amputations and herniorrhaphies stayed longer than other pa* tients on the service. In this dirision second degree burns, breast disorders and collulitis patients had the longest period of originel hospitelisation among general surgery patients routinely discharged.

The length of tay for special services on surgery for prematureif discharged patients are found in the following tables, showing incidence of diagnosis and total hospital stay for the speciel services. Similarly, the length of atay per service and diagnosis is analyzed in duplicate tables for routinely discharged patients.

In the prematurely discharged group amputations and herniorrhaphies required the longest arerage stays in division of general surgery. Fractures and hysterectomies were the next two most costly diagnoses in terms of length of original hospitalization, if the unusually long hespitalizations for gentto-urinary disturbances are discarded from the one hundred prematurely discharged patients. If they are included the five patients on genito-urinary service had the longest average stay of all prematurely discharged patients, thirty-one and one-helf daye. 
The figures on length of stay for various types of fractures require some explanation. Fractures of the $l e g$ and hip accounted, among those promaturely discharged, for an average stay of about nine days per patient, while arm fractures or those of the wrist required only three daye or so. Obviously the patient with a broken leg or hip in long leg cast or traction is mach more difficult to care for at home and requires skilled nursing care longer because he is helpless. Skull fractures, on the other hand, left the hospital soon after admission to neuro-surgery. According to the medical records, in most cases this was because many of these patients were admitted in shock imediately after an accident before $X-r a y$ studies were completes won $X$-ray studies proved negative, in a majority of prematurely discharged patients, they were discharged and not held for the custamary period of longer observation. Routinely and prematurely discharged patients with skull fractures were kept approximately the same average, between one and two days.

Average length of stay for those illnesses which caused the longest or most frequent hospitalizations were compared with the atatistice of New York City municipal and voluntary hospitals, which were compiled for discharges from all types of hospitals in the New York metropolitan area in $1933 . .^{3}$ In the appondix a comparison of these figures is made. In generel Louisville's average stays for both prematurely and routinely discharged groups of patients in the summer of 1946 are much shorter than corresponding hoepitalizations for oimilar conditions in New York

3Neardorf, Hospital Discharge Study, New York Felfare Council, 1933, Appendix X, Vol. I. 
thirteen years ago. Part of this may be due to the general trond in hospital surgery to dismiss patients earlier. However, the results of this comparison of hospitalizations per diagnosis show the great difference curtailment has meant to Louisville patients.

Average stay for certain ilinesses and operations apparently causing the longest hospitalizations anong promaturely discharged patients were compared to the statistics of Nev York City's municipal and roluntary hospitals, which wero compiled for discharges from all hospitals in the metropoliten area in 1933. In general the averages for Louisville General Hospital are shorter than the New York arerages. This is to be expected for routinely discharged pationts as well as prematurely discharged patients of the Louigville study, because of the curtailment policy which affects all groups in the hospital. Thero is also the factor of the change in surgical practice since 1933 when the New York figures were collected; many more surgeons are urging even private patients to recuperate faster than they did a decade ago. Howerer, it is still a great differential botween New York and Louigville patients with the same diagnosis.

The comparison of cortain diagnoses" average hospitalizations in Now York and Louigville may bo examined in detail in the appendix. From the facts certain groups of patients appear to bo particularly affected. The patients with possible skull eractures were the most notably disparate groups. As the generel average for Louisville patients routinely discharged was only $61 / 6$ days, while in New York $62 \%$ of the patients with this diagnosis wore in the hospital from 15 to 30 dajs and $19 \%$ fram 
8 to 14 days, while anothor 12t\% were in the hospital from 31 to 60 days.4 Fractures of the skull in New York ranked first in mortality rates among this group of pationts studied from all voluntary and municipal hospitals in 1933, with 29.1\% of the patients dying, while fractures of pelvis and epine followed in very much lower figures. 5 Seventy of the 1,661 deaths In New York which were due to fractures of any kind concerned children under five years of age, and 50 of these deaths were due to fractured skulls. In Louisvillo in a group of 315 promaturely discharged patienta studied in the course of this investigation, under curtailment since July 1946, there were soveral children admitted with possible skull fractures, later proved negative or not serious by $X$-ray studies, and the patiente were almost all sent home with a atay under fire days in the hospital, and an average stay of about 1t days. In New York it was found in 1933 that $90 \%$ of all the deathe due to skull fracture occurred shortly after hospital admiesion, and $72 \frac{1}{2} \%$ of those due to fracture of pelvis, and about $58 \%$ of those to fracture of the spine also occurred in the first weok after hospital admission. Thus the Louisville staff's decisions to send persons home prematurely was based on previous practice with these patients. If death did not occur suddenly or during the first week after admission, there was reasonablo safety in returning the patient promaturely to his home, to await observation of further difficulty. In Nor York it was found in fracture cases that the danger of death from fracture

Inid.

5Ibid., Vol. II, p. 114. 
41

of any site, particularly of skull fractures decreased steadily and quickly after the first woek following the accident and emergency admission. 6 In Louisville there were many possible skull fractures ruled out from emergency slinic, which were not admitted at all to the crowded wards and, therefore, were not part of this study; this fact makes absoIute comparison between Louisville and New York patients impossible.

In generel the New York study concerning length of hospital stay was quite interesting, as they could. compare such factors as economic bracket, place of residence in the metropolis, type of diagnosis, and age for all their patients in voluntary and nunicipal hospitals alike. 7 They found that "the main determinant of length of stay was the diagnosis of the patient. ${ }^{8}$ Among diagnostic groups where the wajority of discharges ocourred in first woek of hospitalization were chronic infectional hypertrophy of tonsils and adenoid, non-malignant neoplasms, fractures of the upper extremity, abortions, malignant neoplasms, deflection of the septum, and hemorrhoids. As they point out these are not all minor conditions; but sometimes, as in the case of the cancer patients, indicato "transitional hospitalization during the lengthy course of the sickness."9 Nalignant neoplasms were also in the top of the list of diagnoses cauring over-long hospitalizations, two months or more; ${ }^{10}$ as were fractures of the

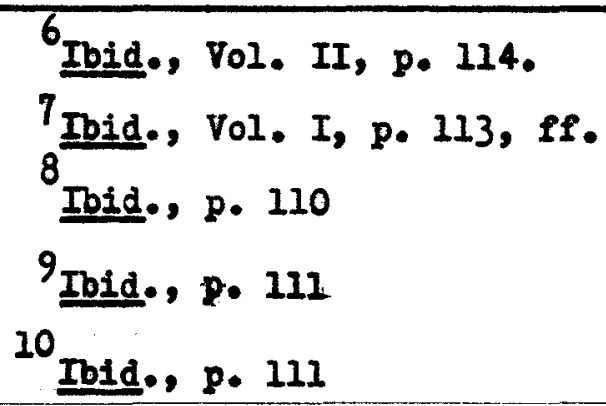


lower extrenity, tuberculosis of the respiratory system, osteonyelitis, otc. In the Now York group orer-long stays were not always due to chronic disease, but often to protracted hospitalization for typical acute conditions, ouch as fracturs of the hip or pelvis. In New York a direct correlation between age and length of hospital stay was shown, and there were increasingly higher proportions of longer stays in each of their diagnostic groups as age advanced. 11 Contrary to the New York investigator's expectations, financiel status: was not found to correlate with length of stay for certain diagnoser.

The New York study was not ablo to distinguish in the matter of readmissions which pationts were readmitted to hospitals for the samo illness (a mattor of transfer, occurring very seldam in Louisville, where there is but one municipal hospital) and those readmitted to other hospitals for recurrences or complications of the original illness. Therefore, their figures are not meaningful to their study as a whole, nor to us in comparing Louisville's experience on readmissions to General Hospital.

The consensus in the New York study on length of stay is worth noting: 12

Length of atey for non-operative putients covers a variety of situations such as those of the patients who cano to the hospital for final diagnostic statements, patients who started a medical therapoutic treatment there to be continued at home, and patients who hare to be hospitalized for a protracted medical treatmont. . . In most instences of major surgery, hospitel service of two to four weoks is noeded to provide pationts with the nocessary post-operative care. In case of appendectony, surgical technique has been developed

11 Ibid., p. 113 .

12 Ibid., Vol. III, pp. 77-78-79. 
to such an extent that most of these patients may leave after less than two wooks' stay, in many instances about olght days after the operation. Approximately $25 \%$ of patients. . . operated in a nonacute stage and thus presenting farorable conditions for rapid recovery, wore discharged within the first two weeks. . . Wata on length of stay of operated patients are significant for the postoperative care of the conditions involved.....

In considering the accompanying tables on average length of hospitalization for diagnostic groups in the study group of prematurely discharged patients it is interesting to compare then with the companion tables on the one hundred routinely discharged patients in the control group. The premature group actually had longer arerage adniesions to general surgery epecial service for four diagnostic groupings lacerations and abscesses; hernias; stab and gunshot wounds; and appendicitis and appendectony. The routinely discharged group had longer average stays in this division for amputations and the category "all other diagnoses." The range of stay was rery widespread as was show in Tables 3 and 4. when the arerage length of hospital stay for pationts admitted on orthopedic service is compared for study and control groups, it can be seen that on the average the prematurely discharged patients stayed for four days longer on the wards than the routinely diccharged patient were kept on this apecial surgical service. Routinely discharged patients stayed on the average about half the average stay of the prematurely discharged patients, though prematurely discharged patients with arm and wrist fractures were discharged after twice the average length of hospitalization of patients in this category who were routinely discharged. Routinely discharged patients stayed an arerage of two more days, or onethird again as long, as the prematurely discharged pationts. Horever, 


\section{TABLE 6 PART I}

INCIDIANCE OF DIAGNOSAS BY TYPE OF SURGICAL SPFCIALIY' GTANERAL SURGERY TOR ONE HUNDRED PATIBNTS PRFMATURELY DISCHARGRD IN JULY AND AUGUST 1946 SHOWING LENGTH OF AVGRAGE STAY AND TOTAL DAYS STAY PER DIAGNOSTIC GROUP

\begin{tabular}{|lclc|}
\hline viagnosis & $\begin{array}{c}\text { No. of } \\
\text { Patients }\end{array}$ & $\begin{array}{l}\text { Average Length of } \\
\text { Hospital Stay by Days }\end{array}$ & $\begin{array}{l}\text { Total } \\
\text { Days Stay }\end{array}$ \\
\hline Total & 37 & General Average 10 da. & 368 days \\
\hline Lacerations, with repair & 8 & $23 / 4$ days & 22 days \\
Hernias and herniorrhapy & 7 & 14 days & 99 days \\
Stab wounds & 4 & $33 / 4$ days & 15 days \\
Appendicitis, appendectomy & 3 & $82 / 3$ days & 26 days \\
Ulcer, skin graft & 3 & $42 / 3$ days & 14 days \\
Amputations & 2 & $271 / 2$ days & 55 days \\
All other diagncess $b$ & 10 & $137 / 10$ days & 137 days
\end{tabular}

${ }^{2}$ Cf. Part IV from which the number of patients on the service is taken. Similar tables will be shown immodiately for the other specialtia.

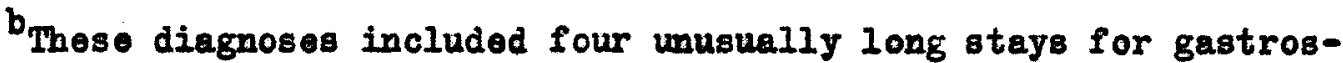
tcay, cholescystectany, cellulitis and burns with grafting (patients already mentioned in the foregoing computation of the arerage length of stay) Ihis group also included, however, diagnooes requiring short stays ranging from one day through seven daye for other patients, having a varlety of diagnoses, including mastectany, trigeminal nouralgia, excision of sebaceous cyst, etc.

the general average for orthopedics as a whole show that the prematurely discharged patients were hospitelized 10 days whilo routinely discharged patient were hospitalized an arerage of 6 daye. Therefore, total daye stay was greater for the study group of prematurely discharged patients than for the orthopedic patients in the routinely discharged category. 
INCIDHNCE OF DIAGNOSES BY TYPE OF SURGICAL SPHCIALTY: ORTHOPEDIC SERVICF* YOR ONE HUNDRED PATIENTS PREMATURULY DISCHARGED IN JULY AND AUGUST 1946 SHOWING LDHGTH OF AVERAGE STAY AND TOTAL STAY PIR DIAGNOSTIC GROUP AT LOUISVIILE GERERAL HOSPITAL

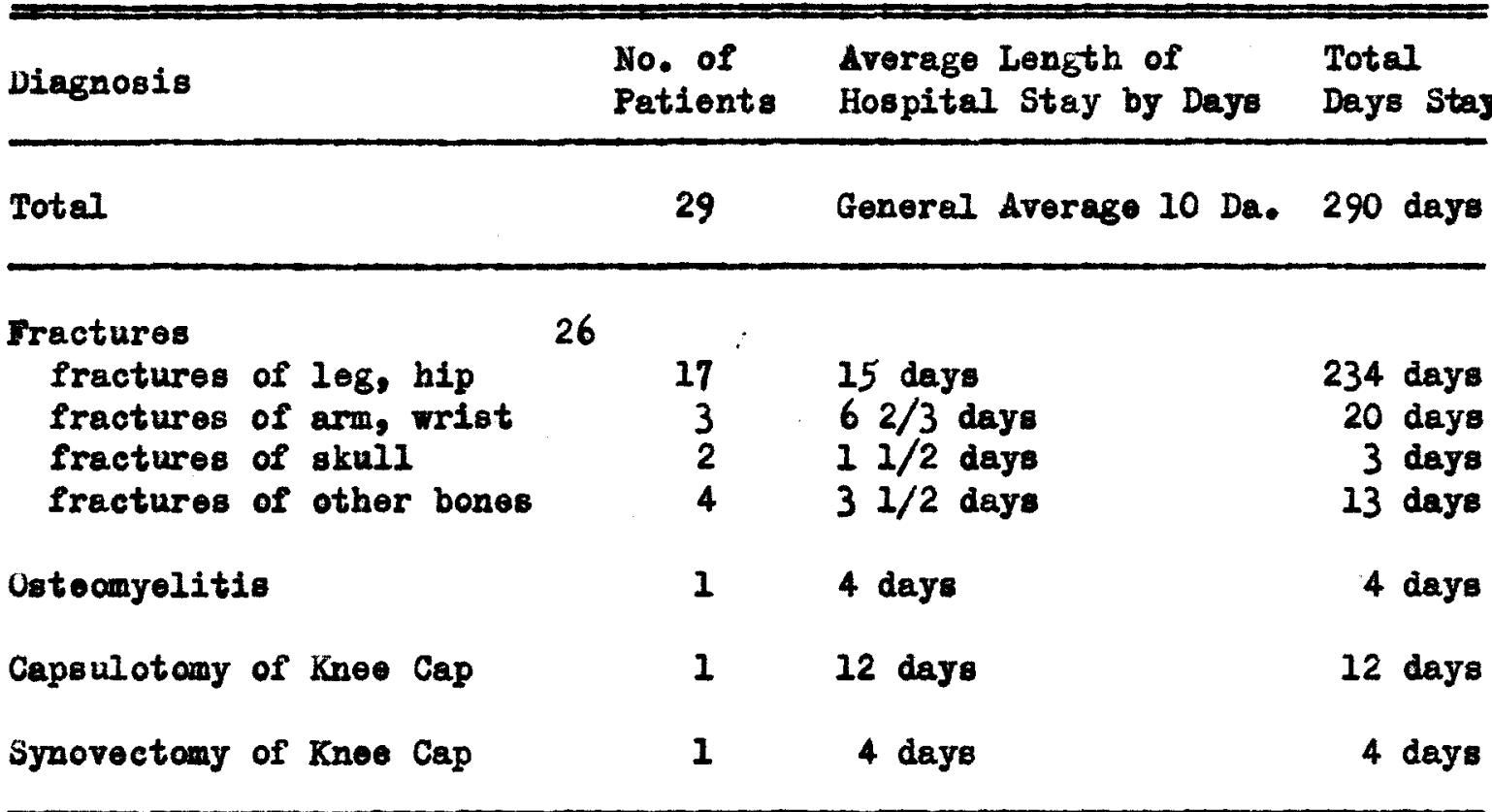

*fe. Part. IV from which the number of patients is taken. Cf. rart I. The range of stay on orthopedic service was from one day through sixty-four days.

This same thing is shown by the table on the next page on gynecology patients' average atay in the premature group, and in its companion table on routinely discharged patients. The total days etay is more than twice as great for prematurely discharged patients on this specialty as for routinely discharged patienta. Again we find the general average for prematurely discharged gynecologicel patients with hysterectomy or other diagnosis is much longer than for routinely discharged patients; eleven days arerage as against five and five-sixths days for routine group. Hysterectomien were the only strictly comparable single diagnostio groups 


\section{TABLIR 6 PART III}

TNCIDENGE OF DIAGNOSES BY TYPE OF SURGICAL SPECIALTY GYNECOLOGY TOR ONE HUNDRED PATIFNTS PRERATURELY DISCHARGED JULY 1946, SHOW-

. ING LENGTH OF HOSPITAL STAY BY AVERAGE NULBER OF DAYS AND TOTAL STAY LOUISVIHLE GRNERAL HOSP ITAL

\begin{tabular}{|lccc|}
\hline Liagnosis & $\begin{array}{l}\text { No. of } \\
\text { Patients }\end{array}$ & $\begin{array}{l}\text { Average Length of } \\
\text { Hospital Stay by Days }\end{array}$ & $\begin{array}{l}\text { Total } \\
\text { Days Stay }\end{array}$ \\
\hline Total & 17 & General Average 11 Da. & 175 days \\
\hline Hysterectony & 13 & $133 / 4$ days & 165 days \\
$\begin{array}{l}\text { Pelvic Inflamatory } \\
\text { Disease }\end{array}$ & 3 & 2 2/3 days & 8 days \\
Foreign Body in Uterus & 1 & 2 days & 2 days
\end{tabular}

The remaining services with a small number of petients per service will be tabulated in Part IV, by sorvice rather than by individual diagnoses.

common to both control and study groups. Besides this diagnostic group, however, other groups spent longer in the hospital in the routinely discharged group than in the prematurely discharged group. The severity of the routine patients' diagnoses is probably the explanation of this fact.

Uther specialties on surgery present an interesting comparison between average length of hospitalisation for patients in the study and control groups. For General Ledicine (or non-operative surgery) the arerage stay of the promaturely discharged patients was eleven days, and of the routinely discharged group, forty days, principally because of one petient who had to stay 165 days. Routine stays on eye service were longer than prematurely discharged patients spent. Proctology had so few pationts no real average could be computed, but the figures were similar 


\section{TABLF 6 PART IV}

INCIDRNGE OF PATIXANS ON SPECIAL SURGICAL SPICIALTIES: GENERAL MEDICINE (NON-OPERATIVI SURGERY), EYIF, PROCTOLOGY, AND GENITO-URINARY SERVICRS

SHOWING LENGTH OF HOSPITAL STAY BY AVERAGE NULBER OF DAYS STAY AND TOTAL STAY LOUISVIILE GFNERAL HOSPITAL

FOR PREMATURE DISCHARGES

\begin{tabular}{|c|c|c|c|}
\hline Surgical Service & $\begin{array}{l}\text { No. of } \\
\text { Patients }\end{array}$ & $\begin{array}{l}\text { Average Length of } \\
\text { Hospital Stay by Deys }\end{array}$ & $\begin{array}{l}\text { Total } \\
\text { Days Stay }\end{array}$ \\
\hline $\operatorname{Total}^{a}$ & 100 & $\begin{array}{l}\text { General Average } \\
103 / 4 \text { deys }\end{array}$ & 1076 days \\
\hline $\begin{array}{l}\text { General Medicine } \\
\text { (Non-operative surgery) }\end{array}$ & 5 & 11 daye & 55 days \\
\hline Hye Service & 2 & 4 days & 8 days \\
\hline Proctology Service & 5 & $41 / 5$ days & 21 days \\
\hline Genito-Urinary Service & 5 & $311 / 2$ days & 159 days \\
\hline Total for General Surgery ${ }^{b}$ & 37 & 10 days & 368 days \\
\hline Totel for Orthopedicsc & 29 & 10 days & 290 days \\
\hline Total for Gynecology $d$ & 17 & 11 days & 175 days \\
\hline
\end{tabular}

This figure is the grand total for all special services, included in the four separate parts of this sectional table.

botals transforred from Part I of the table for cumulative total.

Totels transferred from Part II.

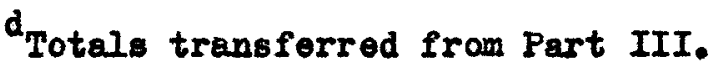

for the two groups. Genito-urinary stays were invariably long in both groups, being several days longer in the prematurely discharged group than in the routine discharges. There was only one neuro-surgical patient in the premeture group, and be was counted in general surgery for 


\begin{tabular}{|c|c|c|c|}
\hline $\begin{array}{l}\text { INCIDEHCS OF DISGNOS } \\
\text { FOR ONE HUNDRED PAI } \\
\text { AUGUST } 1946 \text { SHOH] } \\
\text { STAY } \\
\text { LOUI }\end{array}$ & $\begin{array}{l}\text { TABLE 7 } \\
\text { TIC GROUPI } \\
\text { GIAYGRAI } \\
\text { IFNTS ROUT } \\
\text { NG LENGTH } \\
\text { PER DIAGN } \\
\text { SVIULE GEM }\end{array}$ & $\begin{array}{l}\text { PART I' } \\
\text { IGS BY SPECIAL TYPE OF SU } \\
\text { SURGFRY } \\
\text { NGIY DISCHARGED IN JULY } \\
\text { F STAY (AVRRAGE) AND TOT } \\
\text { STIC GROUP AT } \\
\text { RAL HOSPITAL }\end{array}$ & $\begin{array}{l}\text { GRRY } \\
\text { IND } \\
\text { IL }\end{array}$ \\
\hline $\begin{array}{l}\text { Diagnostic Group on } \\
\text { Special Service }\end{array}$ & $\begin{array}{l}\text { No. of } \\
\text { Pationt. }\end{array}$ & $\begin{array}{l}\text { Average Longth of } \\
\text { Hospital Stay by Days }\end{array}$ & $\begin{array}{l}\text { Total } \\
\text { Days Stay }\end{array}$ \\
\hline Total & 46 & General Average $9 \mathrm{Da}$. & 409 Days \\
\hline Lacerations, abscess & 10 & $13 / 5$ days & 16 days \\
\hline Herniorrhaphies & 1 & 1 day & 1 day \\
\hline Stab, and gunshot wounds & 5 & $14 / 5$ days & 9 days \\
\hline Appendicitis, eppendectomy & 4 & $61 / 4$ days & 25 days \\
\hline Ulcer, burn and grafting & 1 & 37 days & 37 days \\
\hline Amputations & 5 & $33 / 5$ days & 18 days \\
\hline All other diagnoses ${ }^{c}$ & 20 & $151 / 7$ days & 303 days \\
\hline $\begin{array}{l}\text { acf. Table 6, Part } \\
\text { giving comparable figures } \\
\text { General surgery service du } \\
\text { b In the accompeny1 } \\
\text { orthopedics, will be separ } \\
\text { agnoses; while proctology, } \\
\text { be summarizod as they acco }\end{array}$ & $\begin{array}{l}\text { I, which } \\
\text { for the } 3 \\
\text { ring the } \\
\text { ng tables } \\
\text { ated as G } \\
\text { eye, gen } \\
\text { unt for } f\end{array}$ & $\begin{array}{l}\text { a companion table to tl } \\
\text { tients promaturely dis } \\
\text { period of time. } \\
\text { routine discharges, gy } \\
\text { al Surgery is here, by } \\
\text { urinary, neuro-surgery } \\
\text { ationts. }\end{array}$ & $\begin{array}{l}\text { is table, } \\
\text { harged on } \\
\text { ecology, } \\
\text { typicel di- } \\
\text { will only }\end{array}$ \\
\hline $\begin{array}{l}\text { CThese diagnoses } 1 \\
\text { the anklo with okin graft, } \\
\text { vagot ony for duodenal ulce } \\
\text { end stenosis of the jejunu } \\
\text { erage stay for this ontire } \\
\text { pared with the four premat } \\
\text { given in Footnote b of Tab } \\
\text { eral pationt who stayed o } \\
\text { of the neck, (inoperable), } \\
\text { diabetes; and tenorrhaphy }\end{array}$ & $\begin{array}{l}\text { ncluded u } \\
\text { cystic b } \\
r 3 \text { and ga } \\
\text { m; who we } \\
\text { group of } \\
\text { urely dis } \\
\text { lo } 6 \text {, Par } \\
\text { niy one o } \\
\text { tenorrhap } \\
\text { of the fi }\end{array}$ & $\begin{array}{l}\text { lally long stays for ce? } \\
\text { it oczema of breast; tl } \\
\text { oenterostomy for duoder } \\
\text { lentioned in the comput } \\
\text { atine discharges. They } \\
\text { ged petients whose dia } \\
\text { This group included } \\
\text { as in cases of tubercu. } \\
\text { or two days, as oarly } \\
\text { - }\end{array}$ & $\begin{array}{l}\text { ulitis of } \\
\text { racotong: } \\
\text { l ulcer } \\
\text { ion of ar- } \\
\text { uay be com- } \\
\text { 108es are } \\
\text { so, sor- } \\
\text { jus abscess } \\
\text { ingrenous }\end{array}$ \\
\hline
\end{tabular}


TABL 7 PART II

INCIDRNGR OF DIAGNOSTIC GROUPS BY TYPE OF SURGICAL SPRCIALTY ORTHOPEDICS* TOR ONE HUNDRED PATIENTS ROUTINELY DISCHARGED IN JULY AND AUGUST 1946 SHOWING LENGTH OF AVHRAGE IJWGTH OF STAY AND TOTAL STAY PER DIAGNOSTIC GROUP LOUISVIIIE GHNIRAL HOSPITAI

\begin{tabular}{|c|c|c|c|}
\hline Diagnosis & $\begin{array}{l}\text { No. of } \\
\text { Patients }\end{array}$ & $\begin{array}{l}\text { Average Length of } \\
\text { Stay by Days }\end{array}$ & $\begin{array}{l}\text { Total } \\
\text { Days Stay }\end{array}$ \\
\hline Totel & 19 & General Average $6 \mathrm{Da}$. & 114 Days \\
\hline $\begin{array}{l}\text { Fractures } \\
\text { fractures of leg, hip } \\
\text { fractures of arm, wrist } \\
\text { fractures of other bones }\end{array}$ & $\begin{array}{r}11 \\
2 \\
4\end{array}$ & $\begin{array}{l}6 \text { days } \\
7 \text { days } \\
3 \text { days } \\
51 / 4 \text { days }\end{array}$ & $\begin{array}{r}105 \text { days } \\
78 \text { days } \\
6 \text { days } \\
21 \text { days }\end{array}$ \\
\hline Tenosynivitis & 1 & 3 days & 3 days \\
\hline Osteotany of tibia & 1 & 6 days & 6 day \\
\hline
\end{tabular}

6, Part

*Cf. similar table on premature discharges on orthopedics, Table

The range of atay on orthopedic service for this group of routine discharged was from one day, as in cases of fractured ankio and fractured claricle, to thirty-two days for a fractured four. This range was actually not so great as in the case of the twenty-nine orthopedic patients who were discharged prematurely (range from one day through sixty-four days).

that reason. The nourological group of six patients routinely discharged atayed an arerage of six and one-sixth days.

All in all the arerage lengthe of stay for premature patients wrere ton and three-fourthe days, as compered with twelve and seren-tonths days in the routinely discharged group. However, in many categories of opocific diagnoses, and on services which only admitted a small number of patients, the premature patients averaged longer hospitalizations than did patients with the same diagnoses in the routinely discharged group. 
TABLS 7 PART III

INCIDENCR OF DIAGNOSTIC GROUPS BY TYPE OF SURGICAL SPECIALTY GYNECOLOGY FOR ONE HUNDRHD ROUTINELY DISCHARGFD PATIINTS IN JULY AND AUGUST 1946 SHOWING LENGTH OF AVIARAGE STAY BY DAYS AND TOTAL LEHGTH OF STAY LOUISVILIE GHETHRA HOSPITAL

\begin{tabular}{|c|c|c|c|}
\hline Diagnosia & $\begin{array}{l}\text { No. of } \\
\text { Patients }\end{array}$ & $\begin{array}{l}\text { Average Length of } \\
\text { Stay by Daye }\end{array}$ & $\begin{array}{l}\text { Total } \\
\text { Days Stay }\end{array}$ \\
\hline Total & 12 & $55 / 6$ daya & 70 Days \\
\hline Hysterectony & 2 & $111 / 2$ days & 23 days \\
\hline Abortions (and miscarriage) & 4 & $53 / 4$ days & 23 days \\
\hline Cautery of cervix & 2 & $61 / 2$ days & 13 days \\
\hline $\begin{array}{l}\text { Carcinoma of cervix } \\
\text { (radium therapy) }\end{array}$ & 1 & 7 days & 7 days \\
\hline Other diagnoses* & 3 & $42 / 3$ deys & 14 days \\
\hline
\end{tabular}

*This grouping includod all other patients, cases susponsion of the uterus, endometrial hyperplasia for dilatation and curettage, and corvical strain.

Important as the length of hospitalization is the length of time which elapses between an operation and discharge. In the case of prematurely discharged patients this factor should be of oren greater importance than for the routinely discharged patient, for the general rellbeing of the patient, and considering his care at home after discharge. In Table 8 are figures for one hundred patients who were prematurely diecharged. Bighteen femele surgical colored patient who had operations performed during hosptalization stayed an average of seven and one-sixth days after operation. The twelve patients on male surgical colored ward in the study group, who had operations, stayed seren and one-half days, 
51

TABLE 7 PART IV

INCIDRNCR OF PATIENTS ON SPHCIAL DIAGNOSTIC SURGICAU SPECIALTIES,

GENIFRA MGDICINE, FYY, PROCTOLOGY, AND GFNITO-URINARY, AND

NWURO-SURGERY SERVICRS SHOWIING IHNGTH OF STAY BY AVRRAGE

NUIBER OF DAYS STAY AND TOTAL STAY AT LOUISVILLF GHNZRAL HOSPITAL TOR ROUTINE DISCHARGRS

\begin{tabular}{|c|c|c|c|}
\hline Surgical Sorvice & $\begin{array}{l}\text { No. of } \\
\text { Patients }\end{array}$ & $\begin{array}{l}\text { Average Length of } \\
\text { Dayg stay }\end{array}$ & $\begin{array}{l}\text { Totel } \\
\text { Deye Stay }\end{array}$ \\
\hline $\operatorname{Total}^{2}$ & 100 & 12 and $7 / 10$ ths & 1,270 Days \\
\hline $\begin{array}{l}\text { General Medicine } \\
\text { (non-operative surgery) }\end{array}$ & 5 & $\therefore \quad 40$ days $^{b}$ & 201 days \\
\hline Byo Service & 7 & $121 / 7$ days & 85 days \\
\hline Proctology Service & 1 & 4 days & 4 deys \\
\hline Genito-Urinary Service & 4 & $261 / 4$ days & 105 days \\
\hline Neurology Service & 6 & $61 / 6$ daye & 37 days \\
\hline Total for General Surgery & 46 & 9 days & 409 days \\
\hline Total for Orthopedics" & 19 & 6 days & 114 days \\
\hline Total for Gynecologyc & 12 & $55 / 6$ days & 70 days \\
\hline
\end{tabular}

This is the grand total for all patients studied of the routineIy discharged pationte on surgical service, the entire control group.

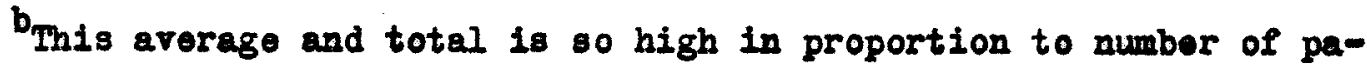
tients on general medicine division of surgical service because of one patient with diabetos, otitis, and degenerative condition of the 11ver who stayed 265 days.

There totals are transforred from the separate Parts I, II, and IIf of Table $T$ on routine discharges, immediately preceding this comperative table.

after operation. The white men stayed an average of about six and onehalf days, and the white women stayed an average of seven and two-fifths 


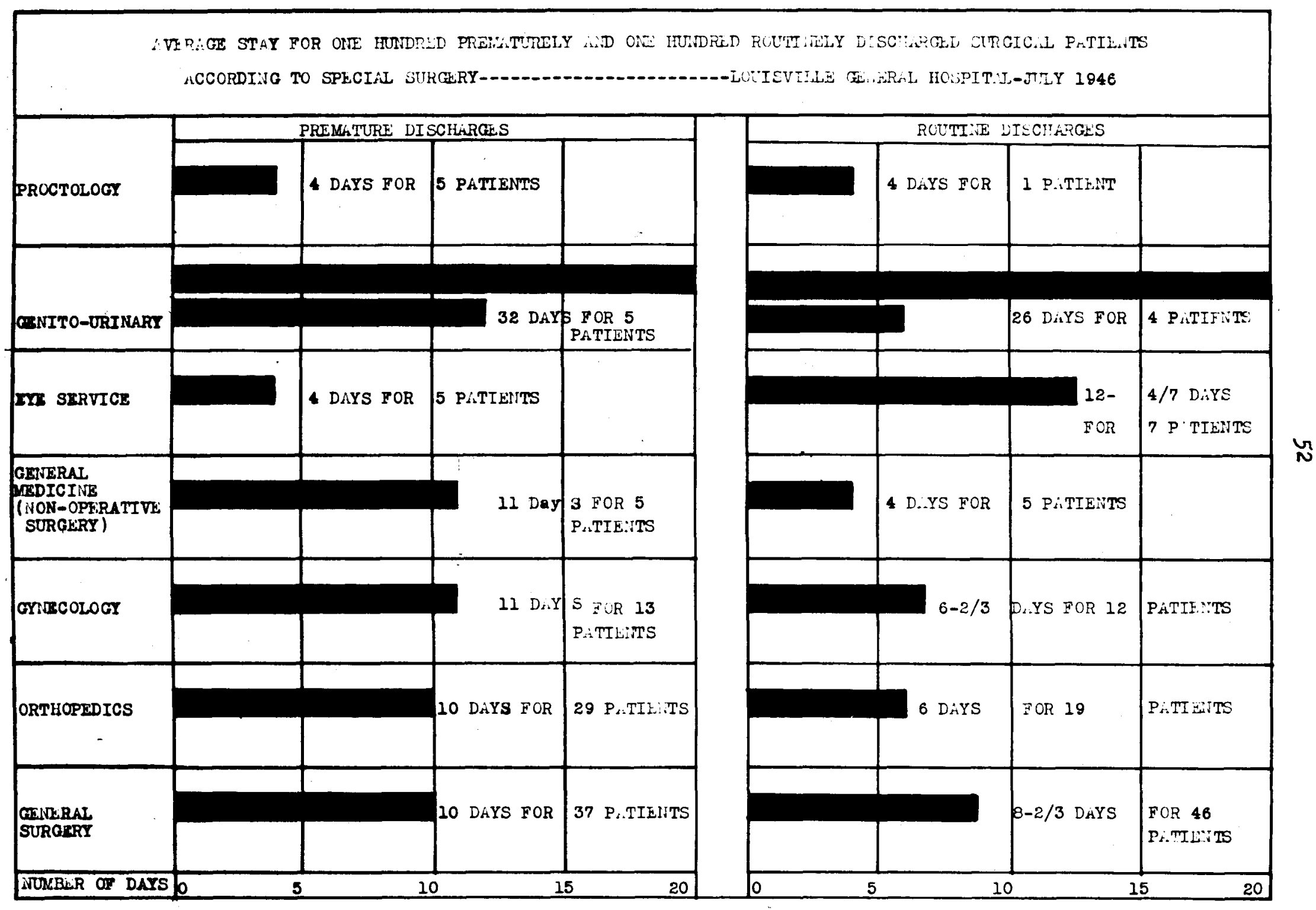

Fig. 3.--Average Stay per Surgical Service of Study and Control Groupg 
days after operation.

Most of the patients who had operations on female colored ward had to have extensive surgery, including cautery of the cervix as well as some type of hysterectomy. The patients on the male wards often had herniorrhaphies performed, staying an average stay of five and two-fifth days after operation. The men who had prostatectomies performed stayed much longer on the arerage, probably due to the greater seriousness of the operation itself and the chronicity of the complaints which require such radical surgical interrention. The advanced age of these pationts might also have been a reason for prolonged hospitalisation after operation, eren in this prematurely discharged group of patients.

By contrast the patients with grafts for ulcers or burns were discharged quite soon after surgery, from one to two days following operation. Amputations kept the patients longer after operation than most other surgical procedures. The same ratio between length of hospitalization and length of stay following surgery was noticed for the group routinely discharged, with more serious procedures requiring longer postoperative stays. The general post-operative average was longer for patients routinely discharged than for those prewaturely discharged.

LNCIDINGS OF RWADUISSIONS FOR RECURRANCES OF ORIGINAL ILLNESS

Readmission is the term applied to the second or third hospitalization of the same patient. Ordinarily statistice are not kept in the hospital record room at General Hospital about readmissions; each time a patient is readmitted to the same or to another service of the hospital, 


\section{TABLE 8}

LFNGTH OF POST-OPERATIVE STAY TOR SEVANTY PATIENTS OF ONE HUNDRED PRIMLTURALY DISCHNRGED PATIMNTS FROY SURGICAL WARDS AT LOUISVILLE GENERAL HOSPITAL JUY 1946 SHOWING TOTALS BY COLORTD AND WHITE WALE AND TMUALB WARDS AND HOSPITAL STAY BY INTBRVALS OF THRRE DAYS

\begin{tabular}{|c|c|c|c|c|c|c|}
\hline $\begin{array}{l}\text { Hospital Stay } \\
\text { (Interval by Dars) }\end{array}$ & $\begin{array}{l}\text { Fomolo } \\
\text { Colored }\end{array}$ & $\begin{array}{l}\text { Male } \\
\text { Colored }\end{array}$ & $\begin{array}{l}\text { Temalo } \\
\text { iphite }\end{array}$ & $\begin{array}{l}\text { Nole } \\
\text { inite }\end{array}$ & $\begin{array}{l}\text { Total } 8 \\
\text { for } 411 \\
\end{array}$ & $\begin{array}{l}\text { tiont: } \\
\text { Varde }\end{array}$ \\
\hline $\begin{array}{l}\text { One day } \\
\text { Two days } \\
\text { Throe days }\end{array}$ & $\begin{array}{l}0 \\
2 \\
2\end{array}$ & $\begin{array}{l}2 \\
0 \\
3\end{array}$ & $\begin{array}{l}2 \\
0 \\
0\end{array}$ & $\begin{array}{l}7 \\
4 \\
2\end{array}$ & $\begin{array}{r}11 \\
6 \\
\frac{7}{24} \text { pto. }\end{array}$ & $\begin{array}{l}\text { tal Days } \\
11 \\
12 \\
\frac{21}{4} \text { days }\end{array}$ \\
\hline $\begin{array}{l}\text { Four days } \\
\text { Five days } \\
\text { Six day }\end{array}$ & $\begin{array}{l}1 \\
0 \\
0\end{array}$ & $\begin{array}{l}2 \\
1 \\
1\end{array}$ & $\begin{array}{l}2 \\
2 \\
0\end{array}$ & $\begin{array}{l}4 \\
1 \\
1\end{array}$ & $\begin{array}{c}9 \\
4 \\
\frac{2}{15} \text { pto. }\end{array}$ & $\begin{array}{l}36 \\
20 \\
\frac{12}{68} \text { dey. }\end{array}$ \\
\hline $\begin{array}{l}\text { Seven daye } \\
\text { aight days } \\
\text { Nine days }\end{array}$ & $\begin{array}{l}3 \\
3 \\
4\end{array}$ & $\begin{array}{l}0 \\
0 \\
0\end{array}$ & $\begin{array}{l}0 \\
1 \\
0\end{array}$ & $\begin{array}{l}0 \\
2 \\
0\end{array}$ & $\begin{array}{l}3 \\
6 \\
4 \\
13 \text { pts. }\end{array}$ & $\begin{array}{l}21 \\
48 \\
36 \\
105 \text { days }\end{array}$ \\
\hline $\begin{array}{l}\text { Ten daye } \\
\text { Gleven daye } \\
\text { Twelve days }\end{array}$ & $\begin{array}{l}0 \\
2 \\
1\end{array}$ & $\begin{array}{l}1 \\
0 \\
0\end{array}$ & $\begin{array}{l}0 \\
0 \\
2\end{array}$ & $\begin{array}{l}1 \\
2 \\
1\end{array}$ & $\begin{array}{l}2 \\
4 \\
4 \\
10\end{array}$ & $\begin{array}{l}20 \\
44 \\
48 \\
12 \text { days }\end{array}$ \\
\hline $\begin{array}{l}\text { Thirteon days } \\
\text { Fourteen days } \\
\text { Fifteen days }\end{array}$ & $\begin{array}{l}0 \\
0 \\
0\end{array}$ & $\begin{array}{l}0 \\
1 \\
0\end{array}$ & $\begin{array}{l}0 \\
0 \\
0\end{array}$ & $\begin{array}{l}0 \\
2 \\
0\end{array}$ & $\begin{array}{l}0 \\
3 \\
\frac{0}{3} \text { pts. }\end{array}$ & $\begin{array}{l}0 \\
42 \\
0 \\
42 \text { daye }\end{array}$ \\
\hline $\begin{array}{l}\text { Sixteon deys } \\
\text { Serenteen days } \\
\text { Eighteen days }\end{array}$ & $\begin{array}{l}0 \\
0 \\
0\end{array}$ & $\begin{array}{l}0 \\
0 \\
0\end{array}$ & $\begin{array}{l}0 \\
0 \\
1\end{array}$ & $\begin{array}{l}0 \\
0 \\
0\end{array}$ & $\begin{array}{l}0 \\
0 \\
\frac{1}{2} \text { pt. }\end{array}$ & $\begin{array}{l}0 \\
0 \\
\frac{18}{18} \text { day }\end{array}$ \\
\hline Nineteen thru Twenty & 10 days & & & & 0 pts. & 0 days \\
\hline $\begin{array}{l}\text { Twenty-two days } \\
\text { Twenty-three days } \\
\text { Twenty-four days }\end{array}$ & $\begin{array}{l}0 \\
0 \\
0\end{array}$ & $\begin{array}{l}0 \\
0 \\
0\end{array}$ & $\begin{array}{l}1 \\
0 \\
0\end{array}$ & $\begin{array}{l}0 \\
0 \\
2\end{array}$ & $\begin{array}{l}1 \\
0 \\
\frac{2}{3} \text { pts. }\end{array}$ & $\begin{array}{r}22 \\
0 \\
\frac{48}{70} \text { days }\end{array}$ \\
\hline $\begin{array}{l}\text { Twenty-five daye } \\
\text { Twenty-six days }\end{array}$ & $\begin{array}{l}0 \\
0\end{array}$ & $\begin{array}{l}0 \\
1\end{array}$ & $\begin{array}{l}0 \\
0\end{array}$ & $\begin{array}{l}0 \\
0\end{array}$ & $\begin{array}{l}0 \\
\frac{1}{1} \text { pt. }\end{array}$ & $\begin{array}{l}0 \\
\frac{26}{26} \text { days }\end{array}$ \\
\hline
\end{tabular}


he is simply counted as another "adraision". Therefore, there were no statistics on file with which to compare the readmission rate found either in the study group of those patients prematurely discherged after curtailment went into effect in July 1946, or in the control group of those patients routinely discharged during the same period. Howerer, a comparison of the study and control groups themselves was made for this important factor of readmissions. Readmissions indicate a number of things about a pationts his dogreo of illness, the type of care needed to continue or to complete his treatment, a recurrence of his symptom necessitating further treatment, sometimes a prolongation of the illness beyond ardinary expectations of the modical and nursing staff, and sometimer they are indices to the patients' tolerance for illness. From the foregoing it should be apparent that for any one patient a readmission may not show all these factors in his medical care; for ome patients readmission will show plainly that tolerance for the illness has broken down for physical and/or for emotional causes, that the patient has succumbed again to his illness to such an extent that he needs organized medicel and nursing care. In other ceses the most importent meaning of a certain readmission may bo the reflection that home care is not sufficient for this person's needs at this time, or perhaps that he is actually in worse condition than at the time of discharge and neods hospital care, perhaps even more acutely than on the first admission; thio is primarily true of those patients in terminal stages of their illnese who must return again and again to the hospital, in spite of good care at home. 
In making this study of premature and routine discharges from Louisville General Hospital, cortain hypotheses wore advanced, among them that readmissions, as a sign of difficulty encountered in the course of medical care, might be expected to re-occur more frequently and more quickly in the patients prematurely discharged then in the patients routinely discharged under curtailment.

For the purpose of the study only those readmissione were considered from the charts that were truly recurrences of the original illness or expected complications; another illness, apparently unrelated to the original diagnoses or to complications, was not considered in tho tabulating of readmissions for either study or control group. Cortain facts about each readmiasion were considered; the length of stay of the original. diegnosed illness, the interval between original discharge and readmissLon, the length of readmission, and whether there were more than ane readfiseion in the period under etudy, which was the six months following discharge for most of the pationts (from July or August 1946 through January or Fobruary 1947).

In the premature group of patients eighteen readmissions were noted for twelve patients. These readmissions totalled ninetymeight hospital days, or an average of eight and one-sixth days per readmitted patient. The total hospital stay, counting readmissions of these twelre patients, was 268 days, or an average of twenty-two total hospitel days per readmitted patient. The average length of readmission was ohort; four of the twelve pationts stayed less than three days on their roturn to the wards. The length of original hospitalization was of course short for 
TABLE 9

DISTRIBUTION OF HOSPITAL DAYS STAY FOR TURLVE PRAMATURHLY DISCHARGHD PATIRNTS AND FOR HIEVIN ROUTINELY DISCHARGED PATIENTS RFADUITTED TO LOUISVIIIT GHARERAL FROM JUY 1946 THROUGH JANUARY 1947

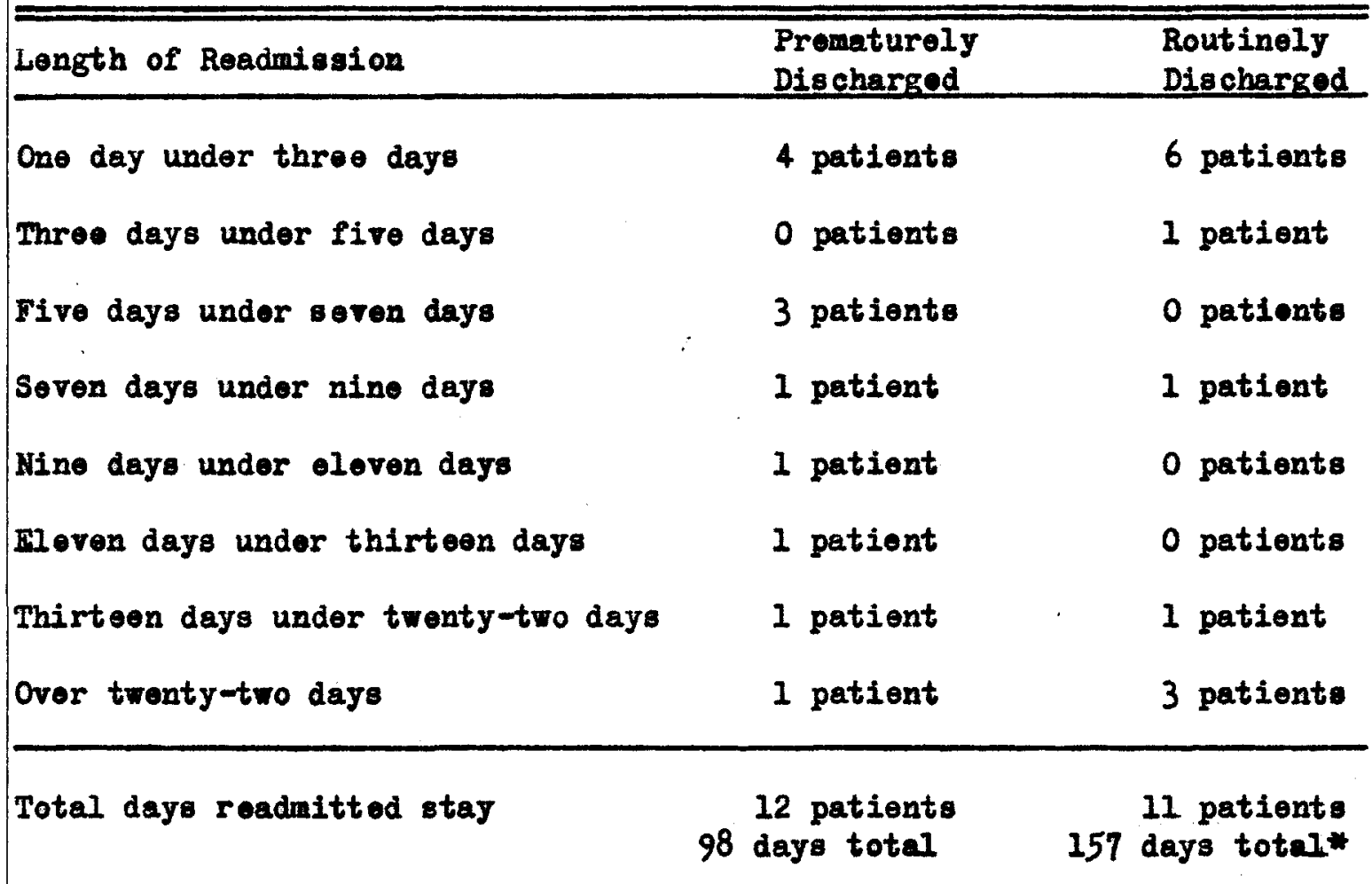

*The total days stay for readmitted routinely discharged patients is higher than that for prematurely discharged pationt $s$ because of the fact that ono patient had to be roadmitted 12 days after his first admission of two days for a 60-day stay, as a boarder, because of lack of commity facilities. Two other patients had hospital roadmissions requiring 30 days each. No one in the prematurely discharged group of patients who had to be readmitted had to remain for the readmission for more than 26 days.

these readmitted patients, as can be seon from the accompanying figure on readmissions for prematurely discharged patients. Conversely their arerage length interval between original discharge and readmission, or botwoen first readmission discharge and later second or third readmission, was quite long. The arerage original admission stay for these twelve 
readmitted patients, prenaturely discharged patients, was fourtoon and one-sixth days, while their arerage interval between admissions and readmissions was twenty-nine and one-half days.

For the routinely discharged patients in the control group the problem of readmissions occurred also twelve times in eleven cases. This is aix times less frequently than in the twelve readmitted patients of the prematurely discharged group, and one $108 \mathrm{~s}$ pationt was affocted in the control group than in tho study group. This factor should bo noted that the number of readmissions was one-third greater in the prematurely discharged pationts than it was in the routinely discharged pationts. They spont 157 days in readinitted stays.

For the most part routinely discharged patients were readmitted for shorter stays then vas true for prematurely discharged patients. The range of readmissions was from two days, the length of time that four of the eleven patients atayed in this group, to eight days, sixteen days, up to sixty days. The arerage length of readmitted stay was thirteen and one-twelth days, and the average stay per readmitted pationt in the group was fourteon and throe-elerenths days. The total hospital stay for these eleven roadmitted patients was 264 days, or an average of twonty-four days per readmitted patient who had been routinely discharged at original admission. The modian length of readmitted stay for this group of paw tients was two and one-half days, wile the modian length of readmiasion for the prematurely discharged group of readmitted patients was six days. The average original atay for routinely discharged patients who had to be readmitted was nine and eight-elevenths days, while the average 
interval between readmissions and original admissions' discharges was twenty and eight-olevenths days. The figures for this group of readmitted patients are shown in the accompanying figure, showing length of hospitalization before routine discharge, interval bofore readmission, length of readmission, and subsequent intervals and further roadmissions. Reasons for readmissions were exacerbations of original illness, as in the case of sarcoma and carcinoma, oczema, gangrene due to diabotes or injury, otc.s complications of the original illness which was reactirated to such an extent that readmission was necessary, as in cases of gangrene dereloping at the site of an amputation, or ulcers dereloping at the donor sites of grafting in burn cases. Sometimes readmissions were clearly the result of mismanagement at home, or of lack of convalescent care in the community. In other cases recurrent illness seaned more related to poor medical care during original admission, or following premature or routine discharge, than to the nature of the illness; this seemed true of the sererel patients who had to be readmitted for the excision of foreign bodies from their original fractures or wounds, and for several pationts who were not completely diagnosed at the original admission. This last factor of improper treatment sometimes seomed closely related to the pationts' uncooperativeness with the modical or nursing staff soreral of them had left against advice.

THE CLINIC CARE OF STUDY AND CONTROL GROUPS AT LOUISVILLE GRNBRAL HOSPITAL, DISCHARGED DURING JULY AND AUGUST 1946

Clinic care is an important phase of the total care of any patient 







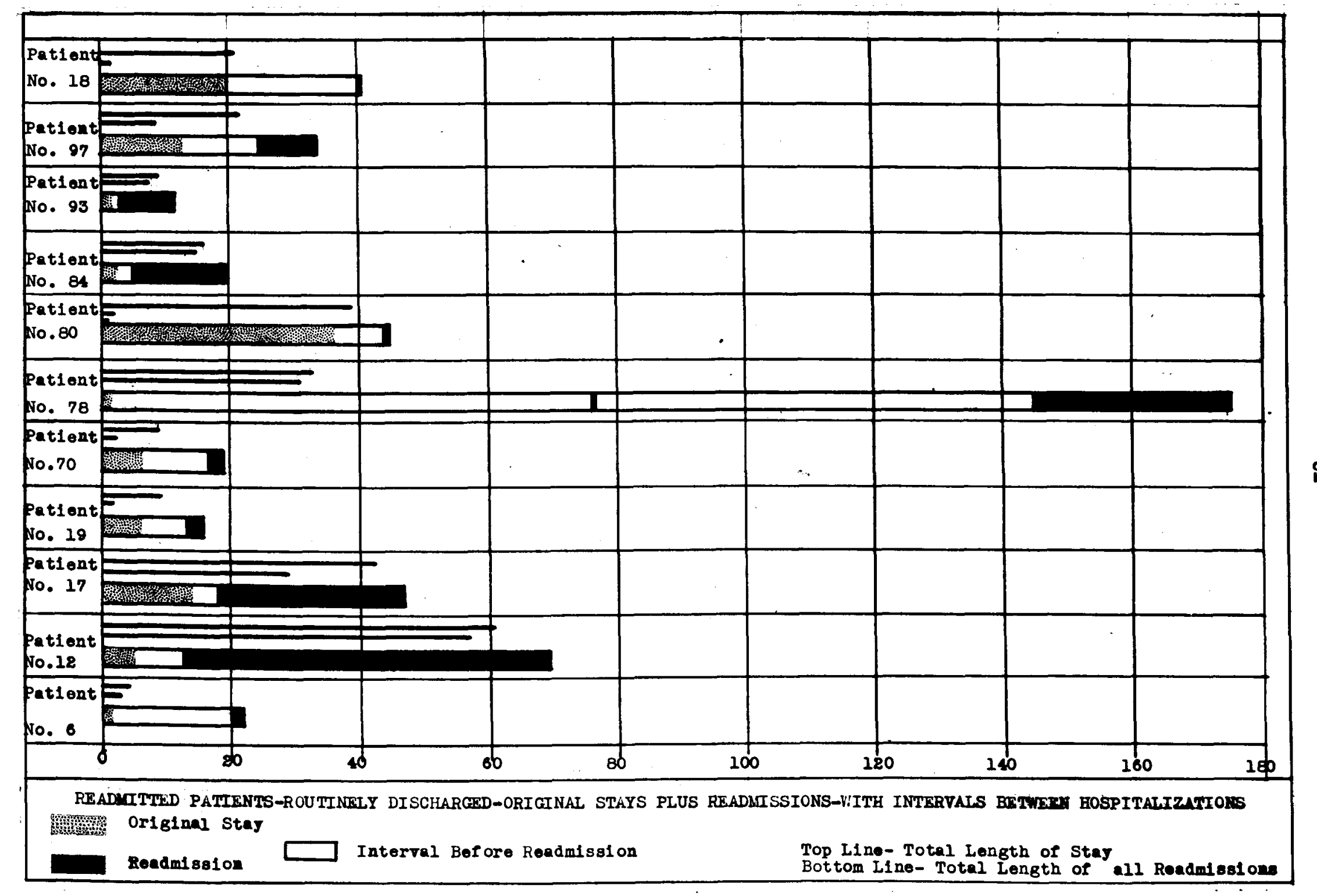

Fig. 5.--Readmissions for Eleven Routinely Discharged Patients 
in a public hospital, or of any public medical care program, for the expense of ward care is too great without the efficient use of the hospital's clinics. Not all patients require the same amount of personal care at the time of their diecharge from the ward, depending upon type of illness or injury, how long they have been in the hospital, etc. The anount and extent and complexity of clinic care may partially depend upon the same factors. In making this study of prematurely discharged patienta, and comparing them with a control group of an equal number of routinely discharged patients who left the hospital during the same weoks as the study group, the hypothesis was advanced that the prematurely discharged group would be found to need prolonged clinic care, in comparison with the control group.

Prolongation and frequeney of clinic care are not always found in the same case, as infrequent clinic attendance may bo prolonged orer an extremely long and debilitating illness; while often the patient whose trouble requires him to come often, as many as three or four times a week to surgery clinic to heve a wound dressed, for instance, may not have to return to clinic more than two or three weoks before he is cured. Therefore, prolongation and frequency of clinic attendance must be thought of principally as indicators of whether the illness is serious and whether the patient is following instructions regarding care after he leaves the hospital. Frequency is perhaps a less accurate measure of the neod of care than is prolongation of clinic attondance.

The factor that concerned the investigator most, in regard to clinic care of both groups of patients, however. discharged, was that 10 
many patients did not return to olinio at all, and many oame only onoe. This definitely meant that the hospital did not know what progress these patients had made after premature or routine disoharge from the ward. This indioated a lack of opoperation on the part of some of the patients who did not return: a lack of proper medical or medioal-sooial follow-up work from the hospital itself or from publio health units in the oity and county which had boen ourtailed at the same time the ward service at General Hospital was ourtailed. In general the indifferenoe of the patients to clinio service in these study and oontrol groups in Louisville is simliar to that of patient groups in many munioipal hospitals. It is ono of the most diffioult problems of publio medioal oare to effect a good modioal follow-up of even the most seriously ill patients.

Clinie care is often dependent upon the oondition of the patient when ho left the ward. If ho was a bed patient upon discharge, the patient would probably postpono olinic care, or perhaps overlook it entirely.

In the group of one hundred prematurely discharged patients, the investigator oontacted serenty patients and the families of four patients who died before the investigation, making a total of seventy-four patients on whom information was secured. Six patients went to other hospitals where they were given bed care. Fifty-eight of the seventy-four patients contaoted were disoharged from General Hospital with orders for bed rest. Most of these patients were cared for by relatives; only elevon were ambulatory or partially ambulatory upon disoharge.

In this study group of prematurely disoharged patients who were 
64

visited all reported that the doctors on the wards had instructed them before they left the hospital as to proper care. Sometimes brief instruction had also been given to the person in the family who was to be responsible for the patient's home care. Private doctors were called by fourteen of the one hundred prematurely discharged patients. These fourteen patients were visited a total of sixty-eight times, or four and six-sevenths times per patient on the everage. This figure is roughly comparable to the number of clinic visits made by other patients, as it represents another type of medical follow-up.

Of the serenty-four petients in this group who were contected twenty-three patients made no clinic visits following their premature discharge, while fifty-one of the seventy-four returned to clinic one or more times. The general average for the prematurely discharged patients was five returne to clinic, or about the same number of times required for follow up care by those who had private physicians at their homes.

Twenty-six prematurely discharged pationts could not bo contacted by the investigator, but their modical records revealod that they, too, returned to clinic very rarely. Then the figures for contacted and noncontacted groups of the prematurely discharged patients are counted, serenty patients returned one or more times, while thirty did not return at 211.

For the routinely discharged group of one hundred patients, there were sixty-six patients who returned to clinic one or more times, and thirty-four patients who failed to return. The number of times that the majority of patients returned, in both study and control groups, ranged 
TABLI 10

NUMBER OF CLINIC VISITS FOR SEVENTY PREMATURALY DISCHARGED PATIFHTS AND FOR SIXTY-SIX ROUTINHY DISCHARGED PATIENTS OF LOUISVILLE GENERAL HOSPITAL SURGERY WARDS FROM JUY 1946 THROUGH JANUARY 1947

\begin{tabular}{lll}
\hline Number of Clinic visits & $\begin{array}{l}\text { Prematurely } \\
\text { Discharged } \\
\text { Patients }\end{array}$ & $\begin{array}{l}\text { Routinely } \\
\text { Discharged } \\
\text { Patients }\end{array}$ \\
\hline One through six visits & 53 patients & 53 patients \\
Seven through twelve visits & 10 patients & 6 patients \\
Thirteen through eighteen visits & 5 patients & 6 patients \\
Orer oightoen visits & 2 pationts & 1 patient \\
Total Number of Pationts & 70 patients & 66 patients \\
\hline Total Number of visits & 335 visits & 330 visits
\end{tabular}

between one and six visits. Fifty-three patients in each group of patient returned under six times to clinic. As can be seen in the accompanying table on the number of clinic visits for study and control groups, this represents about two-thirds of those patients of both groups who kept any clinic appointments. Wen it is remembered that thirty prematurely discharged patients and thirty-four routinely discharged patients failed to return at all to clinic, in spite of orders to do 80 , it can be soen how littlo the clinic facilitios are used.

Only fourteen patients, including those from both study and control groups, had to attend to clinic more than twelve times, which is an 
extensive treatment procedure for surgical cases.

For the promaturely and routinely discharged patients, alike, the greater number of persons returned less than seven times to clinic. Very few persons returned more than twelve times to any one clinic. Some patients had to attend as many as three different clinics in order to obtain followup care. The prematurely and routinely discharged patients wore quite similar in the matter of clinic attendance.

The scarcity of patients roturning more than ten times to the clinics after discharged, whether premature or routine, indicates again what an acutely ill group of patients we are considering, for it is principally chronically ill persons who usually fill the clinics, for long periods of time. Many of the patients interviewed said they were feeling fairly well, or were trying to work, when the time for their first clinic appointment came; they gave these reasons for failure to complete the outlined program of clinic care. Others were not able to get transportation to clinic at the proper time, and gave up attendance because of its difficulties. Fifty-nine of the seventy-four prematurely discharged patients interviewed came back to clinic too few times to complete treatment outlined by their doctors when they left the wards or later when they returned to clinics. At the time of the study medical care was still not complete for some of these patients, and many who have not completed care believe they are now well. About eighty percent of the premeturely discharged pationts failed to follow directions regarding clinic care. Of course, there are some patients whose illness is such that though they have followed diractions for care in clinic, their 
medical care is still not complete; these pationts should not be confused with those who failed to follow directions.

Reasons for prolonged clinic care in either group are interesting. Fissentially the same factors seam to operate, no matter whether the patient was counted as a premature discharge or a routine discharge when he left the hospitel. The nature of the diagnosis is the prime determinant of the type of clinic care needed. Burned patients, persons with infections from stab or gunshot wounds which required frequent dressings in surgery clinic, had to return eighteen and twenty times to clinic. Another diagnosis which caused trouble and frequent visits, after promature or routine discharge, were prostatectomy and cyatoscopy; here we are dealing with chronic disturbances and with delicately balanced organs of the body; it should be remembered that it was these same diagnoses which kept both groups of patients in the hospital for the longest original stays, and which in several cases caused their return to the hospital for readmission after premature or routine discharge. In both cases of prostatectomy age and general health were additional factors of importance in delaying rocovery and in causing prolonged clinic attendance, often with poor results for the patient.

In anolyzing those promaturely discherged pationts' records who returned to clinic twelve times or more, in most instances it seomed that a good choice had been made for premature discharge and prolonged clinic care by which a saving of ward façilities could be effocted. Patients meoding prolonged and frequent physiotherapy treatments, or treatment in varicose voin clinic, could come to the hospital for a sogment of each 
TABLE 11

DIRGNOSRS CAUSING THE YOST FRE ¿UENT CLINIC VISITS FOR ONG HUNDRBD PREMTURELY DISCHARGAD PATINATS FRON LOUISVIILE GIRNARAL HOSPITAL JULY 2946 AND

ONE HUNDRED ROUTMILY DISGLARGED PATIGNTS

WITH RWTARENGS TO THE SPECIAL

SURGICAL SIMRICR

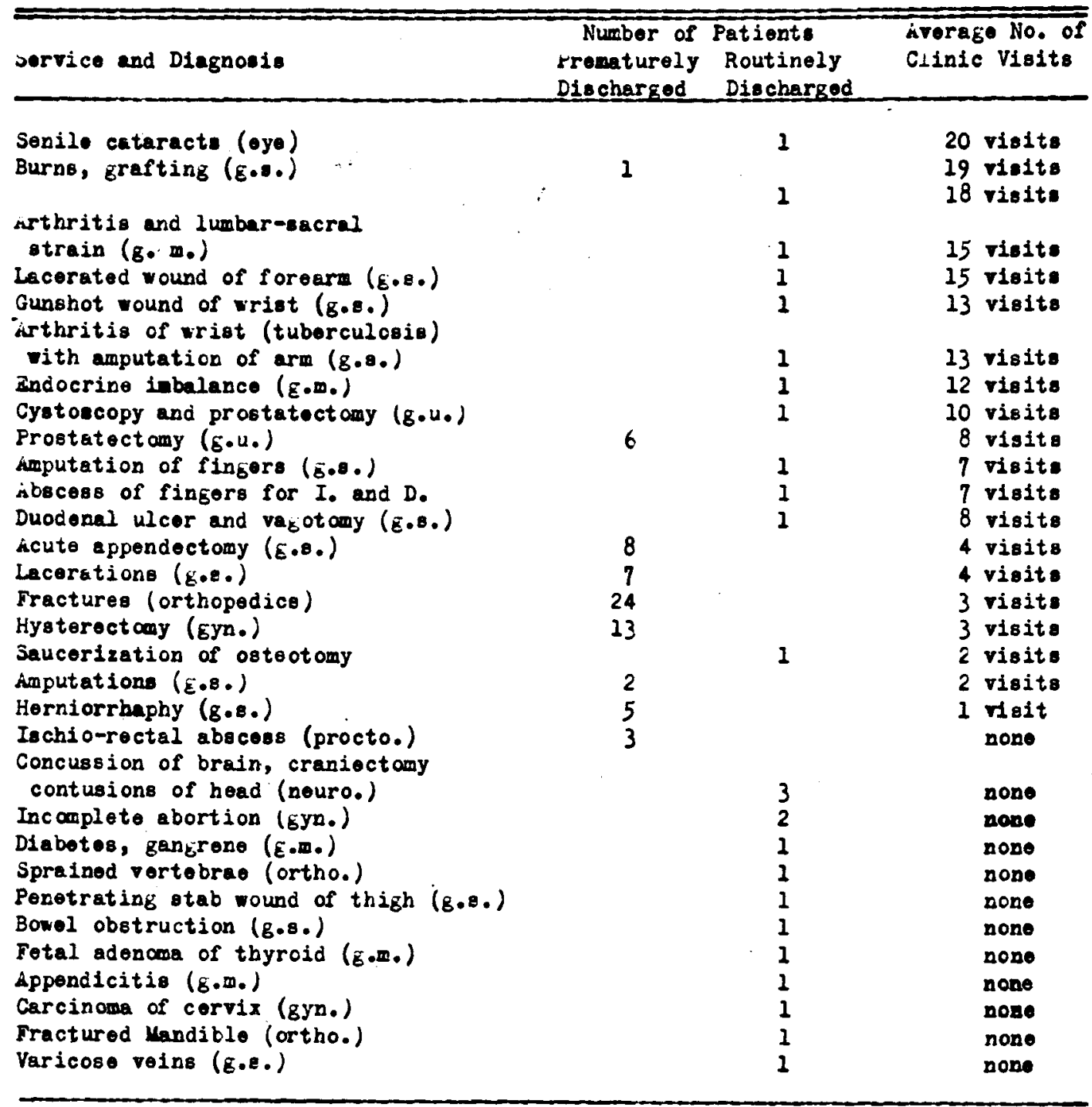

thile this is not a complete listing of all diagnoses for both groups it is suggeative of those diegnoses whore petients most frequently felt the noed of continued clinic care after discharge; those diagnoses for wich pationts did not seok clinic care. 
day, wen necessary, and carry on their convalescence at home, better than on the hospital wards. Apparently those patients were cared for at home, and did very well with occasional visits to the clinfes.

Certain operations and conditions required only a small average number of visits to clinic after discharge, whether routine. or premature. Hysterectomies and herniorrhaphies were among the less taxing operations, in this respect, even though the originel hospitalization may have been prolonged in relation to many premature and routine discharges' hospitelizations. Clinic visits were apparently helpful in most instances, and there were no complaints from the group of patients interviewed, about the clinic routine or nursing, as most patients realized under what difficulties the hospital was maintaining service. The expense of clinic visits was heary, however, especially for those patients who had to come by cab or ambulance, and it was also very difficult for ill persons to come on the crowded busses and street-cars.

The accompanying table on the frequency of clinic visits by diagnoses and surgical specialty shows the number of clinic visits in control and study groups; although it is not a complete listing of all diagnoses, it is indicative of the illnesses which caused the most frequent, as well as the least frequent clinic attendance. It only indirectly measures the extent or prolongation of clinic cere. 


\section{CHAPTER III}

\section{A SUMNARY OF FINDINGS}

As it has been shown in the chapter on the historical aspects of curtallment at Gonoral Hospital, Louisville and Jefferson County faced a problem of health administration which is apt to recur on tax-supported modical programs, or tex-supported programs of other types, such as welfare departments, institutions for the care of childron, the aged, or other special groups of the population dependent upon the general public for their support. In many respects the Louisville experience of curtailment, demanded by the roality of increasing costs of operation of the Health Depertment which was not met with increased tax-support, has been a common one in other commuitios in America. It wust be realized that the philosophy of general public cocial services and health services is of rather recent development in the United States, where the philosophy of political laissez-faire prevailed almost untouched until the depressIon of the $1930^{\prime} \mathrm{s}$ and the reorganization for war production and mobilization of man-power in the second World War. Therefore, it is not surprising that local comunities with such a laissez-faire outlook still prevailing should still find it difficult to get tex-support for such public wolfare activitios as public hospitals and clinics, nurses and doctors, as well as for other nooded social services. 
Progress. In the social soiences is very slow and growth is often a matter of political trends, such as the New Deal swing toward state intervention in business, protection of labor and active Federal partioipation in the sooial services. Suoh trends also have a way of reversing themselves through the inertia and unooneern of the taxpayer. Therefore, Louisville's experience is only typical and is not necessarily a permanent aspeot of health provision for the oitizens of Louisville and Jeffers on County. This does not imply, however, that a continued ourtailment of funds to be spent by the Health Department oould be tolerated for very long by the community without definite damage to the physical well-being of a large group of oitizens unable to procure private modical care because of insufficient inoome. Modioal care is increasingly expensive to purchase individually, beoause of the highly speoialized nature of the practioe of modioine and surgery of all types, and the prohibitive prioe to almost the total oommunity of very speoial skills such as some operations, psychiatrio oonsultation or treatment, eto. Therefore, it should be a serious ooncern to the oitizens of any community whenever their Health Department is unable to funotion properly due to any oause. It is partioularly serious whon this oause is lack of governmont finanoing whioh has already been planned by previous legislators, but which is not implemented by tax appropriations in the proper amounts. The whole matter is oonoerned with the tax-raising and budgeting funotions of look, state and even of Federal governments, but the direct consequenoes will be felt by the poorer groups of the population who must depend on the taxsupported services for medical oare. 
In this study the direct results of curtailment of hospltal service at Louigrille General Hospital has been oxamined from the experience of two similar groups of patients of the Hospital. Wo may assume that each group was roughly similar in financial background, the section of community from which they came, and the amount of other social services they might have required. This assumption cen be made from the previous experience of the hospital adminietration and from the generally shared fact of their eligibility to General. Hospital. The difference between the two groups was an erbitrary one, the fact of premature discharge after a hospitalisation, or of routine discharge. These terms were der fined by the phyaicians in charge, and in many cases it was apparent that the terms were not rery different in their meaning. For instance, the length of hospital stay was very closely similar in the two groups when patients in both groups with the same diagnosis were compared. In many cases it is true, of course, that ono patient may stay for a day with one diegnosis and because of the general condition before injury or some other factor may be quite ready for discharge and therefore considered a routine discharge, while another patient with an ideatical injury, fron the surgical point of view, might have a disposition to illness, a serlous emotional or psychic reaction to an injury or illness resulting in psychosomatic complaints that might make hospitalization very desirable; and if this latter patient is discbarged after ono day's care in the hospital, the doctors rightly feel they have discharged a pationt prematurely, before he was ready to leare without risk to his future hoalth. Therefore, the concepts of routine and premature discharge are 
largely relative ones, whioh are subjeot to many variable faotors in each patient's condition or disposition. They are useful for comparison, however, as they give us a method by which patients who are treated under a general ourtailment of servioe may be studied.

since ourtailment meant that fewer patients oould be served at any given time on the wards, it oalled for a polioy of quick turnover of beds on each ward which was left, and this in turn demanded some suoh polioy as the "premature disoharge" if a great number of patients urgently needing surgery were to be served by the hospital. This curtailment meant that service was restrioted to aoutely ill or emergenoy oases of injury on the surgioal servioe, because the ward space was not large enough to acomodate eleotive surgery patients any longer. This was also true of general modioal patients and of pediatrio patients under ourtailment. It was espooially true of almost all obstetrio patients, exoept those patients with the most serious oomplications of ohildbirth. The psyohopathio wards were not affeoted beoause of particular problems of care in the community which they represented, and the fact that there were no private faoilities within reach of the families of these patients

A seoond result of ourtailment was to deny oare to ohronioally ill patients of Jefferson County and of Louisville, except the limited oustodial faoilities of the Hom for the Aged and Infirm at Shively. This is a natural result of the ourtailment of faoilities for acutely ill patients. In the end ohronioally ill patients will have to be provided for by the Health or Welfare Departments and the ourtailment plan only confirmed the trend of negleot of these patients, postponing 
the day when care for thom can be planned syotematically.

From the facts of this study it would seem that curteilment has had the expected results on the medical care of patients at Goneral Hospital. Length of hospital care has been shortened for both groups, which represent a sample of the total population of surgical patients, to such an extent that the difference botween premature stay and routine stay is practically nogligible. Clinic care has been maintained for both groups, and used in practically the same ratio by both groups, whother routinely or prematurely discharged. Readmiseions have occurred in both groups with equal frequency, and the possible factor of causation in the premature discharge has not been proved, though in indiridual cases it might be demonstrated in later readmissions.

When the results from obvious records of the medical charts and from the statements of the prematurely discherged patients are counted it is found that the prematurely discharged patients who were interviewed did not think premature discharge had much influenced the course of their illnesses and most of them claimed recovery or improvement of health, and wore satisfied with care received. The proportion of patients who wore aick, well, or partially disabled after premature discharge, can be compared with the number of this same group who stated thoy wore satisfied or dissatisfied with hospital or clinic care.

In goneral it can be dotermined from this study that promature discharge or some such messure of hospitel administration was necessary for curtailment of hospital service, and that the results have fallen with about equal force on those patients routinely and prematurely discharged 
from surgery. Therefore, curtailment has affected the general hospital population rather than only a specific group, those prematurely discharged. Standards of care have been maintained at the cost of shorter and less complete service on the wards for all patients, however they may hare boen designated at the time of their discharge.

Medical service has actually improved, as measured by the number of internes on surgery service. As in many of the civilien hospitals, the war-time shortage of internos has decreased, and Genoral Hospital had during curtailment its pre-war number of rosident staff, with seventyseren internes and twenty-oight doctors on rotating interneships, 1 and twonty-one surgical residents and three residents on anesthesia care for the surgery patients. ${ }^{2}$ Nursing service has also been increased since 1945-1946 from the arerage of six-tenths of an hour per day per patient to the arerage of one and one-half hours per day per patient in 19461947.3 This nursing sorvice is given on the surgery service by twentyfour graduate and student nurses. 4 The ratio of student to graduate nurse in the hospital is rory high. Most wards have a nursing supervisor who is a graduate, and sometimes there is an assistant, with the bulk of bedside nursing done by students under supervision of the graduate.

'statements from ur. W. C. walton, Hospital sdminiatrator, Genoral Hospital, March 1947.

2Ibid.

3 statements from the Office of Nursing Service and Nursing Education, General Hospital, Warch 1947.

${ }^{4}$ Statement from Mr. Walton's office, 10c. oit. 
However, the hospltal has not been able to keep all the positions authorized for graduate nurses filled with graduates during this curtailment year. 5

Since the curtailment moasure in July 1946, there have been varLous readjustments in the fiscal policy. These have been notable in that there has been continued effort on the part of the Health Director and his Board to gain an increase of finances for the Department's various services, from whatever revenue sourses seemed available. The Municipal Bridge funds were one source of help. Another source of support for the hospital was the oavinge from the hospital's operating budget, which resulted largely in the ability to keep all graduate nurse's positions filled. This made it possible for the Hospital to roopen forty of the beds which had been closed by the curtallment order on March 1st, 1947. These beds can only be operated until the ond of the fiscal year, June 30, 1947. 6 It is hoped by the edministration that sufficient funds will be appropriated for the new fiscal year to allow these beds to continue in use, but think it probable that the hospital will again have to discontinue use of these beds at the beginning of the new fiscal year when the funds saved this year are used up.

From the material in the study it would seom advisable for tho medical ataff to make greater use of the social service department in making plans for prematurely and routinely discharged patients, but

${ }^{5}$ Letter from H. W. 'C. Walton to investigator, Hay 15,1947 . 'Ibid. 
particularly for the prematurely discharged group. When those patients were interviewed the meaning of their illnesses were discussed, and many could have been helped to more complete and effective medical care following discharge if a careful modical social plan had been made. With continued efforts to improve the nursing service to the entire patient group, General Hospital ought to be able to maintain reasonably satisfactory hospitel service to the individual who can be admitted to the ward, in spite of curtailment. It has been shown by the replies of those promaturely discharged, that nursing service was the only serious complaint roiced against the hospital, and the patients themselres discounted the effect of premature discharge on their recovery.

Curtailment was designed as temporary measure to belance the budget of the health department of the city and county. It was not considored a permenent aspect of public medical care in the community, and was looked upon by the administrators as a nocessary adjustment, but a dangerous one if followed for too long a time. The practice of premature diøcharging, for instance, had never before been employed at General Hospital before curtailment made some such meesure necessary. Whilo curtailment is conceived as a temporary measure, and its effects on a small sample group of the hoepital's population in 1946-1947, has boen shown not to have been serious, it cannot be argued frow these facts that continued curtailment of needed health servlces should be tolerated by the community. No basic changes in the organization of the Health Department have been made because of the fact thet curtailment is thought of as only a temporary measure. However, the decision is up to the tax- 
appropriating bodies of the city and county governments. Curtailment for a short time is unfortunate, but for an extended time might have serious -ffects on the health of the community, the confidence of the public in public medical services.

Hospital service is an important aspect of health organization of any community. The number of patiente corred under curtailment is roughIy holf the estimated number which should be provided free or partial-pay care in a community of Louisville's size. Therefore, the Louisville Department of Health should have the support of the community in providing increased and expanded health services, rather than in curtailing badly needed services in all its branches.

Hospital service is a community problem, just as public education and sanitation, and tax appropriations must bo made with this fact in mind in order to effect future savings to the community on its total health bill. 


\section{APPENDIXBS}

I. YONHHLY STATISTICS FOR LOUISVILLE GHNGRAL HOSPITAL JULY 1946-APRIL 1947

TABLE 1

NUMBER OF PATIENTS PREMATURELY AND ROUTINELIY DISCHARGID

\begin{tabular}{|c|c|c|c|}
\hline Intervel & $\begin{array}{l}\text { Prematurely } \\
\text { Diecharged }\end{array}$ & $\begin{array}{l}\text { Routinely } \\
\text { Discharged }\end{array}$ & $\begin{array}{l}\text { Total Number } \\
\text { Discharged }\end{array}$ \\
\hline July 20-Sept. 6 & 481 & 562 & 1,043 \\
\hline Sept. 7-0ct. 6 & 347 & 350 & 697 \\
\hline Oct. 7-Nov. 6 & 318 & 486 & 804 \\
\hline Nov. 7-Dec. 6 & 354 & 421 & 775 \\
\hline Dec. 7-Jan. 6 (1947) & 349 & 417 & 766 \\
\hline Jan. 7-Teb. 6 & 280 & 481 & 761 \\
\hline Feb. 7-Mar. 6 & 282 & 381 & 663 \\
\hline Mar. 7-Apr. 6 & 302 & 497 & 799 \\
\hline Apr. 7-llay 6 & 273 & 507 & 780 \\
\hline Totale & $\begin{array}{r}2,986 \\
\text { pationte }\end{array}$ & $\begin{array}{r}4,102 \\
\text { patients }\end{array}$ & $\begin{array}{r}7,088 \\
\text { patiente }\end{array}$ \\
\hline
\end{tabular}

*The figures for total discharges do not include deaths.

The atatistics were taken from Iigures compiled in the Record Room at Louisville General Hospital. 
80

I. YOWHLY STATISTICS FOR LOUISVIILE GENERAL HOSPITAL JULY 1946-APRIL 1947

TABLE 2

AVERAGE LENGTH OF HOSPITALIZATION FOR ROUTINELY AND FOR PREMATURELY DISCHARGIFD PATIINTS

\begin{tabular}{|c|c|c|c|c|}
\hline Interval & $\begin{array}{l}\text { Patients } \\
\text { Prematurely } \\
\text { Discharged }\end{array}$ & $\begin{array}{l}\text { Average } \\
\text { Hos pital } \\
\text { Stay (Days) }\end{array}$ & $\begin{array}{l}\text { Patients } \\
\text { Routinely } \\
\text { Discharged }\end{array}$ & $\begin{array}{l}\text { Averago } \\
\text { Hospital } \\
\text { Stay (Days) }\end{array}$ \\
\hline July 20-Sept. 6 & 481 & $7 \cdot 3$ & 562 & 10.9 \\
\hline Sept. 7-oct. 6 & 347 & 5.5 & 350 & 11.8 \\
\hline Oct. 7-Nov. 6 & 318 & 5.1 & 486 & 10.3 \\
\hline Hov. 7-Dec. 6 & 354 & 3.9 & 421 & 11.5 \\
\hline Dec. 7-Jan. 6 (1947) & 349 & 4.2 & 417 & 11.4 \\
\hline Jan. 7-Feb. 6 & 280 & 5.0 & 481 & 11.0 \\
\hline Fob. 7-Mar. 6 & 282 & 5.2 & 381 & 12.4 \\
\hline Mar. 7-Apr. 6 & 302 & 6.0 & 497 & 11.8 \\
\hline Apr. 7-May 6 & 373 & 4.9 & 507 & 11.2 \\
\hline
\end{tabular}


81

I. YONTHLY STATISTICS FOR LOUISVIIIE GRNHRAL HOSPITAL JULY 1946-APRII 1947

TABLE 3

COMPARISON OF 1946-1947 CURTAIULENT WITH 1940, 1945

\begin{tabular}{|c|c|c|c|}
\hline & 1940 & 1945 & $2946-1947^{*}$ \\
\hline Routine Discharges & 11,499 & 12,788 & 4,102 pationts \\
\hline Premature Discharges & $: 0$ & 0 & 2,986 pationts \\
\hline Total Discharges & 12,499 & 12,788 & 7,088 patients \\
\hline Average Monthly Discharge & 957 & 1,065 & 787 patients \\
\hline $\begin{array}{l}\text { Daily Average Number on } \\
\text { Warde }\end{array}$ & 421.9 & 392.9 & \\
\hline Average Number of Days Stay & 12.4 & 10.5 & $\begin{array}{l}5.2 \text { days for } \\
\text { premature } \\
11.4 \text { days for } \\
\text { routine } \\
8.3 \text { days for } \\
\text { both }\end{array}$ \\
\hline
\end{tabular}

*The figures for 1946-1947 are for the nine month period under atudy--July 20, 1946, through May 6, 1947. 


\section{COPY OF LETTER FROU HOSPITAL ADMINISTRATION \\ LOUISVILLA AND JEPTERSON COUNTY BOARD OF HEALTH \\ Louisville 2, Kentucky}

May 15, 1947

Miss Ruth C. Davidson

156 Serenth Street, N. E.

Atlanta, Goorgia

Dear Miss Davidsons

Please pardon my delay in replying to your letters of April 14, 1947, one of which was addressed to me, and the other to Dr. John J. Phoir. . . . I am attempting to answer the questions you asked of Dr. Phair as follows

1. The bed capacity at the General Hospital was increased about Marchl, 1947 by forty (40) beds. Funds nocessary to operate these additional beds for the balance of this fiscal year (June 30,1947 , inclusive) wero roalized from savinge on our operating budget, resulting largely from our inability to keep all graduate nurse positions authorized filled. It is probable that wo shall have to discontinue these additional beds at the beginning of our new fiscel year, unless a sizable increase is granted over last year's appropriation for operating requirements. We, of course, hope that sufficiont funds will be appropriated to permit the reopening of our closed wards, and the operation of the hospital on a normal basis, during the fiscal year of $1947-1948$.

2. - - Since the Board's original release, there has been some reallocation of funds between the facilities operated by the Board, and the Department has boen provided with additional funds in the amount of $\$ 42,000.00$ by the City of Louisville. . . .

3. The practice of discharging patients prematurely has never, to my knowledge, been in effect at the General Hospital, prior to the per iod covered by your study, beginning about July 1,1946 . . . . .

- - .If you find that you need some further help, kindly do not hesitate to call upon us.

WCW:ejh

Very cordially yours,

/B/ W. C. Walton

W. C. Walton

Administrat or

inc.

Louisville General Hospitel 


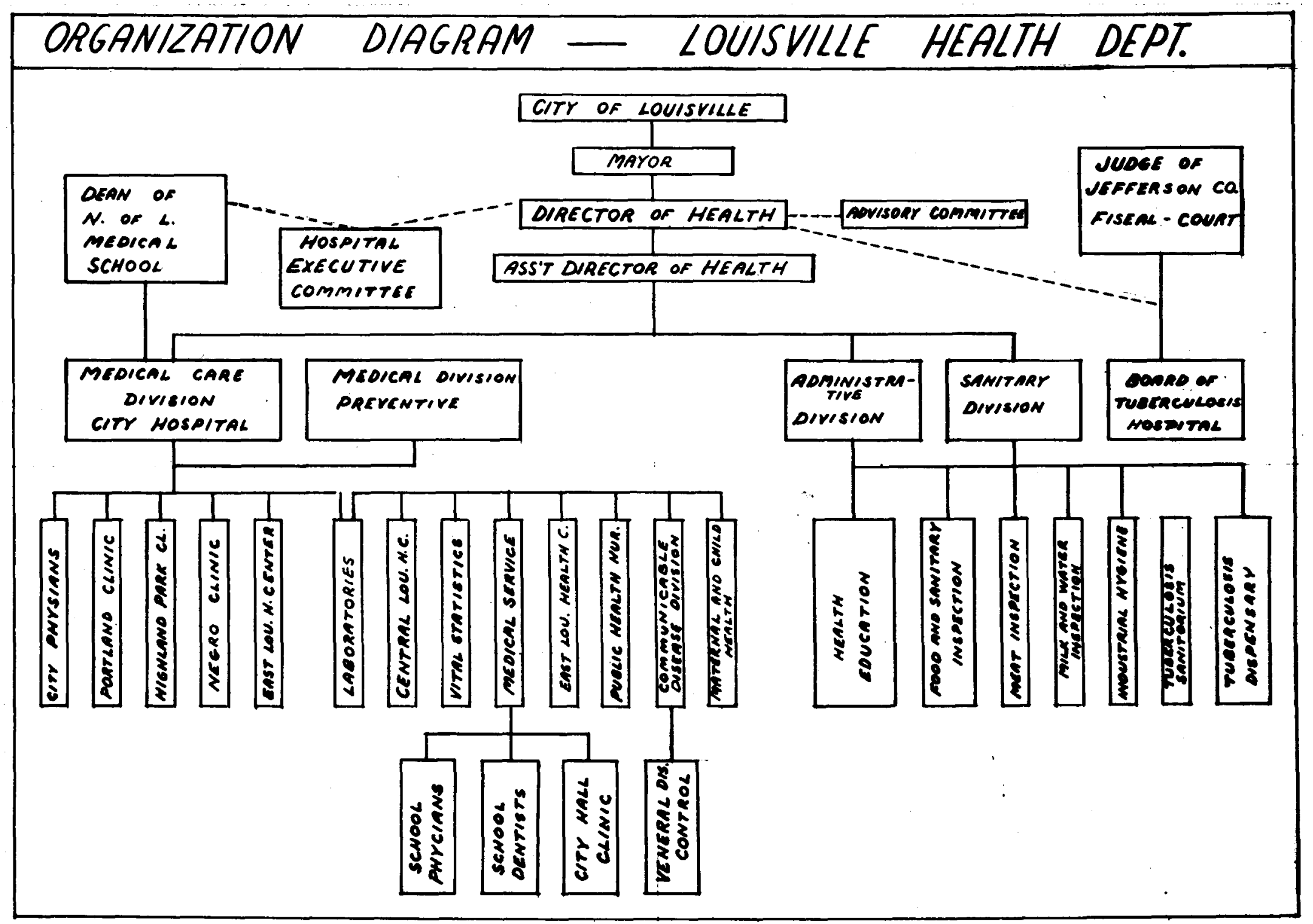

$\stackrel{-H}{-\infty}$

Fig. 1.--Organization of Louisville Health Department and City Hospital before mergor with Jofferson County Heal th Department. 
CHART NO. 5

\section{LOUISVILLE AND JEFFERSON COUNTY BOARD OF HEALTH}

\section{WAVERLY HILLS SANATORIUM}

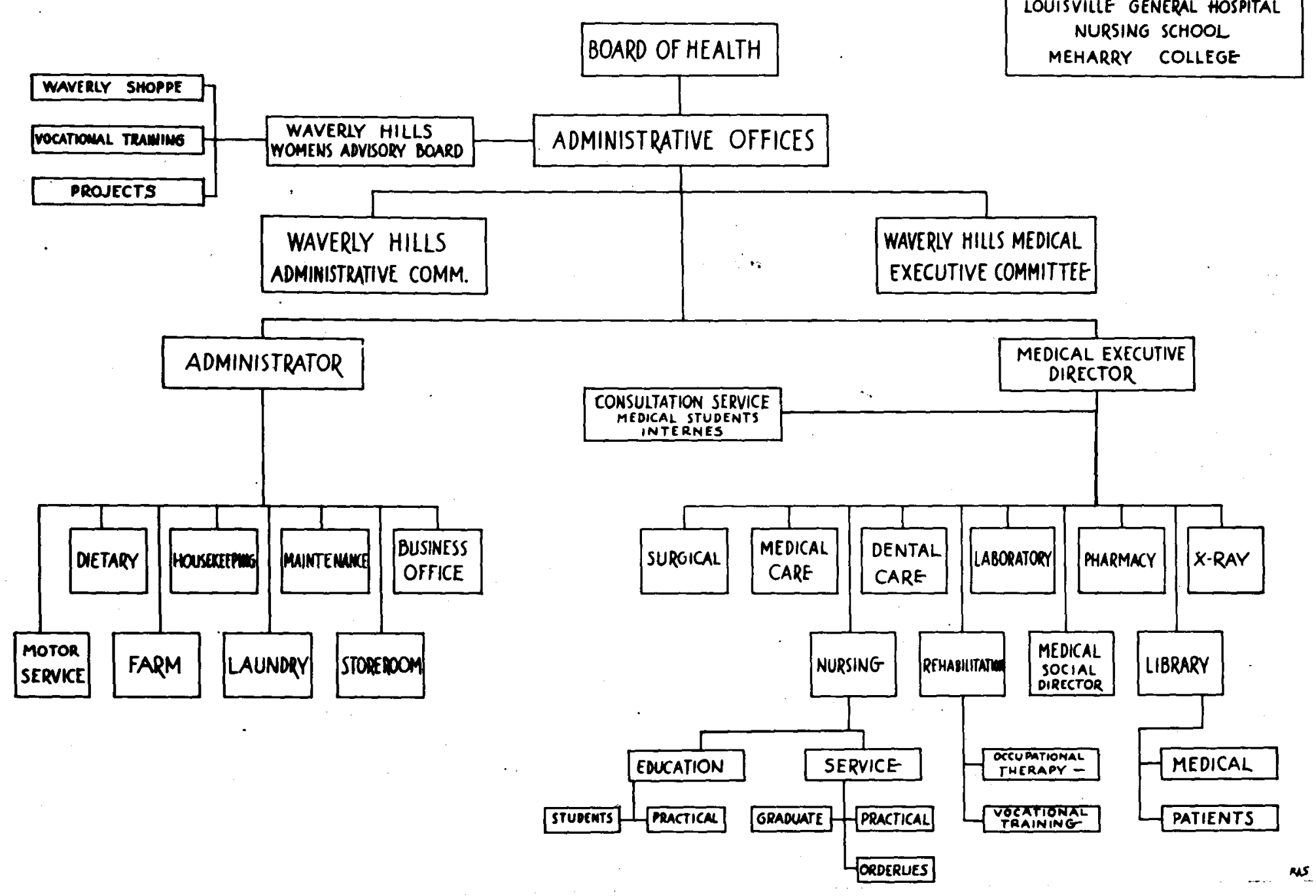

Fig. 2.--Organization of Louisville and Jefferson County Board of Health, General Hospital and Waverly Hills Sanatorium after merger of Louisville and Jefferson County Health Departments. 


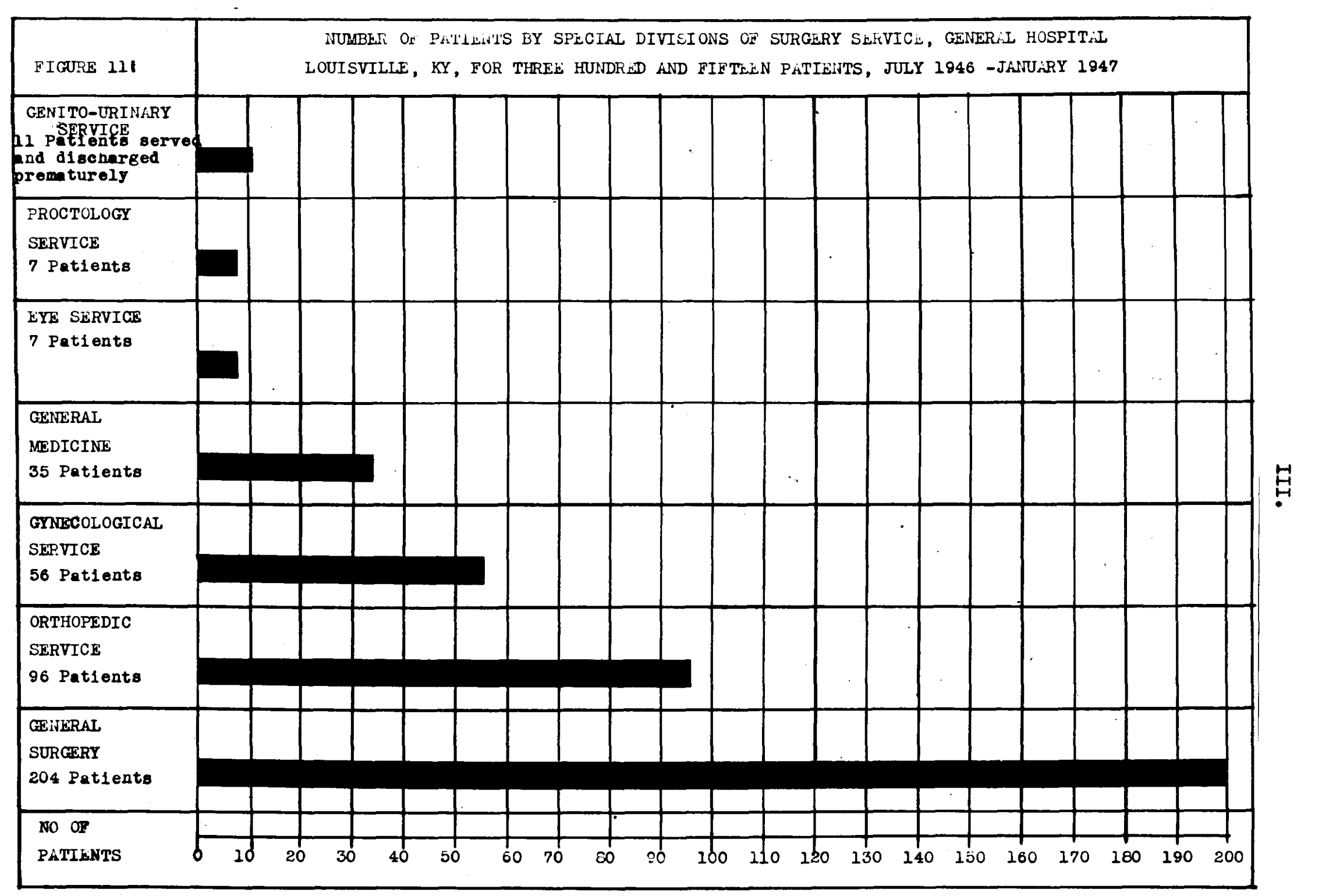

Fig. 3. 
III. LZNGTH OF HOSPITAL STAY FOR JALACTAD DIAGNOSTIC GROUPS OF PATILWTS AT LOUISVILLE GEY BRAL HOSPITAL JUY-AUGUST 1946 COUPARAD WITH

PATINNTS IN VOLUNTARY AND MUNIOIPAL HOSPITALS IN

NEN YORK CITY $1933^{\circ}$

TABLE 4

\begin{tabular}{|c|c|c|c|}
\hline Diagnosis & $\begin{array}{l}\text { Now York Patients } \\
\text { (Routinely Dis- } \\
\text { charged) }\end{array}$ & $\begin{array}{l}\text { Loulsvilo Pationte } \\
\text { Promaturely } \\
\text { Diecharzed }\end{array}$ & $\begin{array}{l}\text { (Arorage) } \\
\text { Routinaly } \\
\text { Diecharged }\end{array}$ \\
\hline Hernia & 14 to 28 days & 14 days & $1 \operatorname{day}^{b}$ \\
\hline $\begin{array}{l}\text { Appondicitie } \\
\text { (acute) with } \\
\text { oporation }\end{array}$ & $\begin{array}{l}8 \text { to } 30 \text { days } \\
\text { for } 93 \% \text { of pts. }\end{array}$ & $82 / 3$ days & $61 / 4$ days \\
\hline without operation & $\begin{array}{l}1 \text { to } 14 \text { days } \\
\text { for } 82 \% \text { of pts. }\end{array}$ & $\begin{array}{l}\text { no patients without } \\
\text { in oither study gr }\end{array}$ & $\begin{array}{l}\text { operation } \\
\text { roup }\end{array}$ \\
\hline Fractures, leg, hip & $\begin{array}{l}1 \text { to } 7 \text { days }-33 \% \\
8 \text { to } 14 \text { days }-16 \% \\
15 \text { to } 30 \text { days }-165 \% \\
31 \text { to } 60 \text { days }-13 \%\end{array}$ & $15^{\circ}$ days & 7 days \\
\hline $\begin{array}{l}\text { Frectures of arm, } \\
\text { wrist }\end{array}$ & $\begin{array}{l}1 \text { to } 7 \text { days }-57 \% \\
8 \text { to } 14 \text { days }-16.6 \% \\
15 \text { to } 30 \text { days }=14.8 \% \\
31 \text { to } 60 \text { days }-8 \%\end{array}$ & $62 / 3$ days & 3 days \\
\hline Frectures of skull & $\begin{array}{l}1 \text { to } 7 \text { days }-13 \frac{1}{2} \% \\
8 \text { to } 14 \text { days }-192 \% \\
15 \text { to } 30 \text { days }-62 \% \\
31 \text { to } 60 \text { days }-12 \frac{1}{2} \%\end{array}$ & $\begin{array}{l}1 / 2 \text { days } \\
\end{array}$ & $61 / 6$ days \\
\hline Osteonyelitis & $\begin{array}{l}1 \text { to } 7 \text { days }-27 \% \\
8 \text { to } 14 \text { days }-19 \% \\
15 \text { to } 30 \text { days }-21 \% \\
31 \text { to } 60 \text { days }-15 \% \\
\text { oror } 60 \text { days }-19 \%\end{array}$ & 4 days $^{b}$ & 4 days $^{b}$ \\
\hline Homorrhoids & $\begin{array}{l}1 \text { to } 7 \text { days }-47 \% \\
8 \text { to } 14 \text { days }-45 \% \\
15 \text { to } 30 \text { days }-7 \% \\
31 \text { to } 60 \text { days }-9 \% \\
\text { over } 60 \text { days }-2 \%\end{array}$ & $41 / 5$ days $^{\circ}$ & 4 days $^{b}$ \\
\hline $\begin{array}{l}\text { Genito-urinary } \\
\text { disturbances }\end{array}$ & $\begin{array}{l}1 \text { to } 7 \text { days }-27 \% \\
8 \text { to } 14 \text { days }-25 \% \\
15 \text { to } 30 \text { days }-25 \% \\
31 \text { to } 60 \text { days }-15 \% \\
\text { orer } 60 \text { days }-9 \%\end{array}$ & $311 / 2$ daye & $261 / 4$ deys \\
\hline
\end{tabular}

These averages are taken from tables in Vol. II, Now Yark Wolfare Councll, Hogpital Dibcharze Study, 1943.

bAverages so marked refor to a "grouping" of only one pationt.

CThis average is for petients with proctological diagnoses, including homorrhoids, and rofors to a group of five pationts. 
IV. PATIBNTS KNOWN TO SOCIAL SHRVICE AND HGALTH AGHNCIFS

The one hundred patient in the study group of prematurely discharged patients were cloared with Social Service Bxchange for registrations of health and social agencies in the comunity. Figures $4,5,6$, and 7 show the frequency with which cortain agencies were consulted or with which their services were used by our petients. No similar study was made of the one hundred patients routinely discharged.

In tabulating the results of this part of the study a division was made between those patients known to social service or health agencies after 1945, 1946, and 1947 and those who were known only in earlier years. Iigure 4 of this appendix contrasts patients known prior to 1945 but not oince 1945 by type of agency, those patients' families known to heialth agoncies, and those known to welfare agoncies. These figures show frequency of registration of various agencies rather then the per patient use of these agencies because many of the patients were known to several agencies.

Both health and velfare agencies are divided for the purposes of graphing their registrations into sub-heads by function of the agency. Those agencies giving primarily relief and assiatance or full care (as in the case of institutions like General Hospital and Home for the Aged and Infirm) are dissimilar from those agencies whose functions are primarlly to render spocific and limited service to the generel community. These service agencies included public health nursing services, visiting nurses, 
health clinics, the Social Sorvice Department at General Hoopital, and many private agencies rendering case work service such as Legal Aid Society or family service.

On the wholo, service agencios helped the patients more frequently than did relief agencies or institutions giving full care. Some agencios such as family aervice organizations and children's agencies had combinod functions of relief and service.

Of the one hundred prematurely discharged patients, twenty-seven per cent were not known to any social or health agency at any time. This would illustrate that group of medically indigent patients who are normally self-reliant and self-supporting members of the community until illness strikes. They are not usually able to purchase expensive medical care and were eligible for public modical care. It is interesting that of the one hundred patiente thirty-seven per cont were known prior to 1945 but were not known to health or welfare agencies after 1945. This gives a total of sixty-four per cont of the prematurely discherged patients who managed on their own resources without help even from a service agency in the fact of their illness and premature discharge. This indicates practically a two-thirda mority of patients promaturely discharged who were self-sufficiont and dopended on the community only for the provision of emergency modical care through the public hospital.

Only thirty-six per cont of our patients prematurely discharged were known in 1945 and 1946 and only eight per cont of this group had any clearings since July 1946 when the period of this study of premature discharges began. Therefore, we would conclude that premature discharge 
was not factor in causing rogistration with social or health agoncies. of the patients studied there were no increases that could be primarily shown to be due to premature dis cherge. 


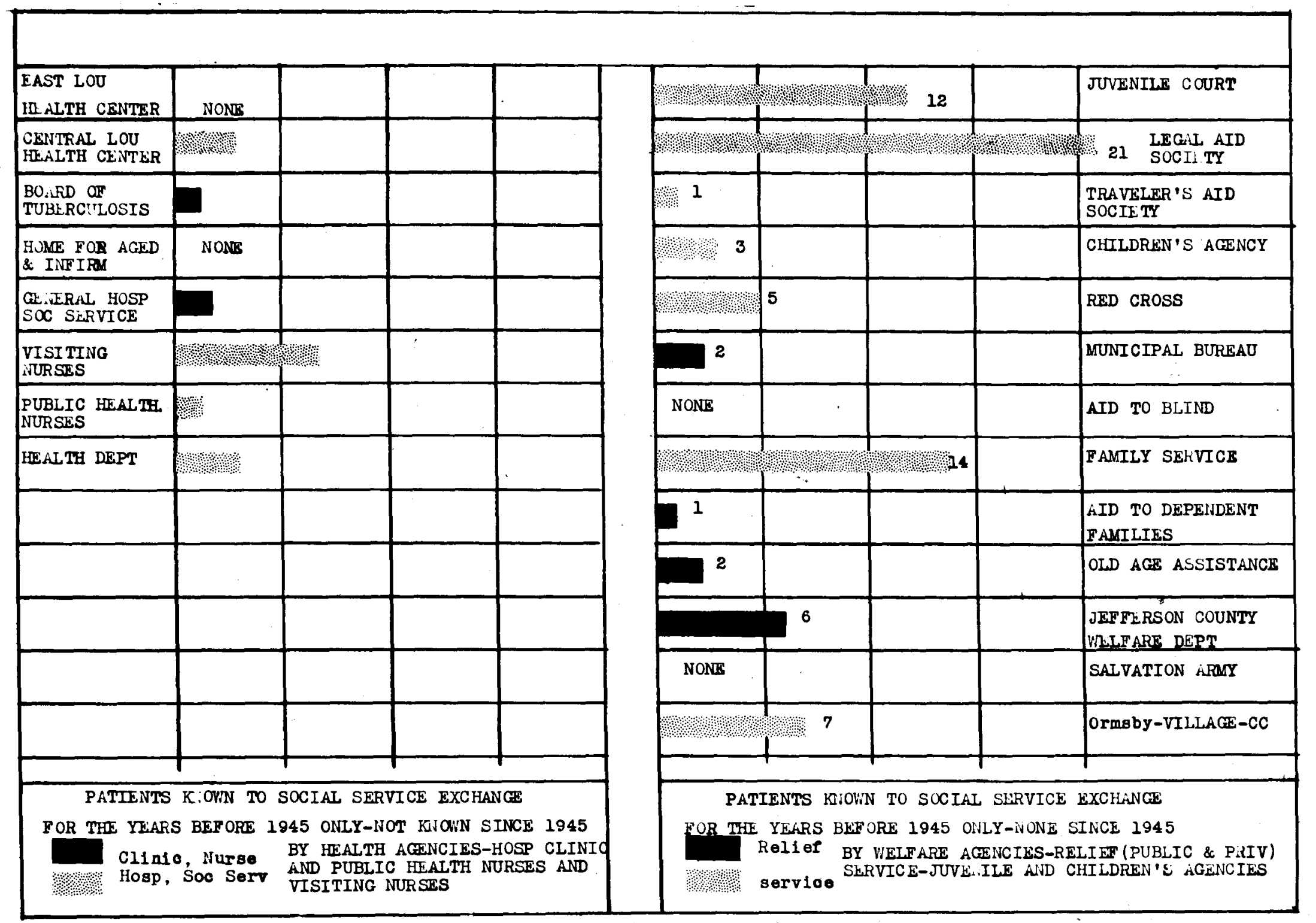




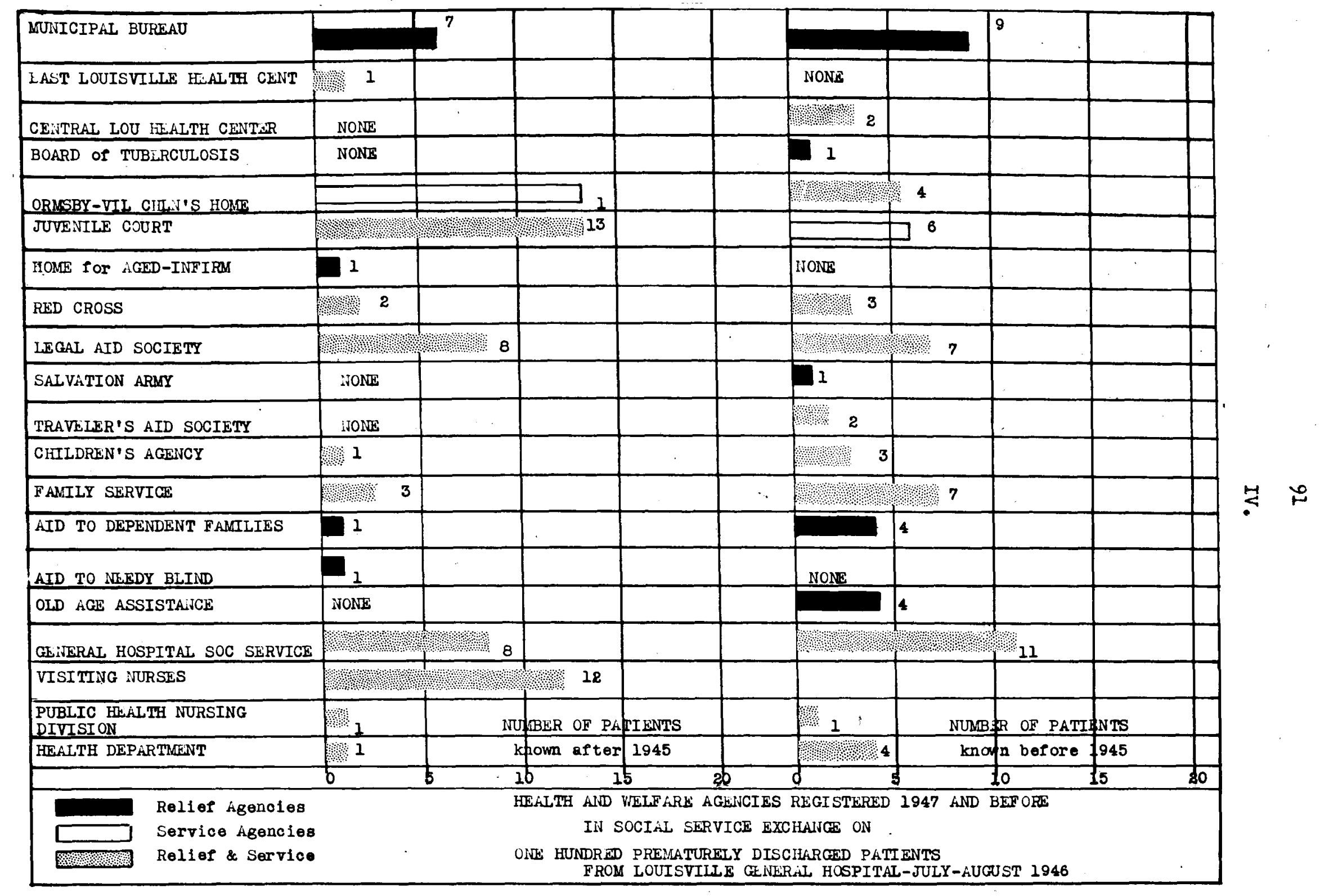

Fig. 5. 


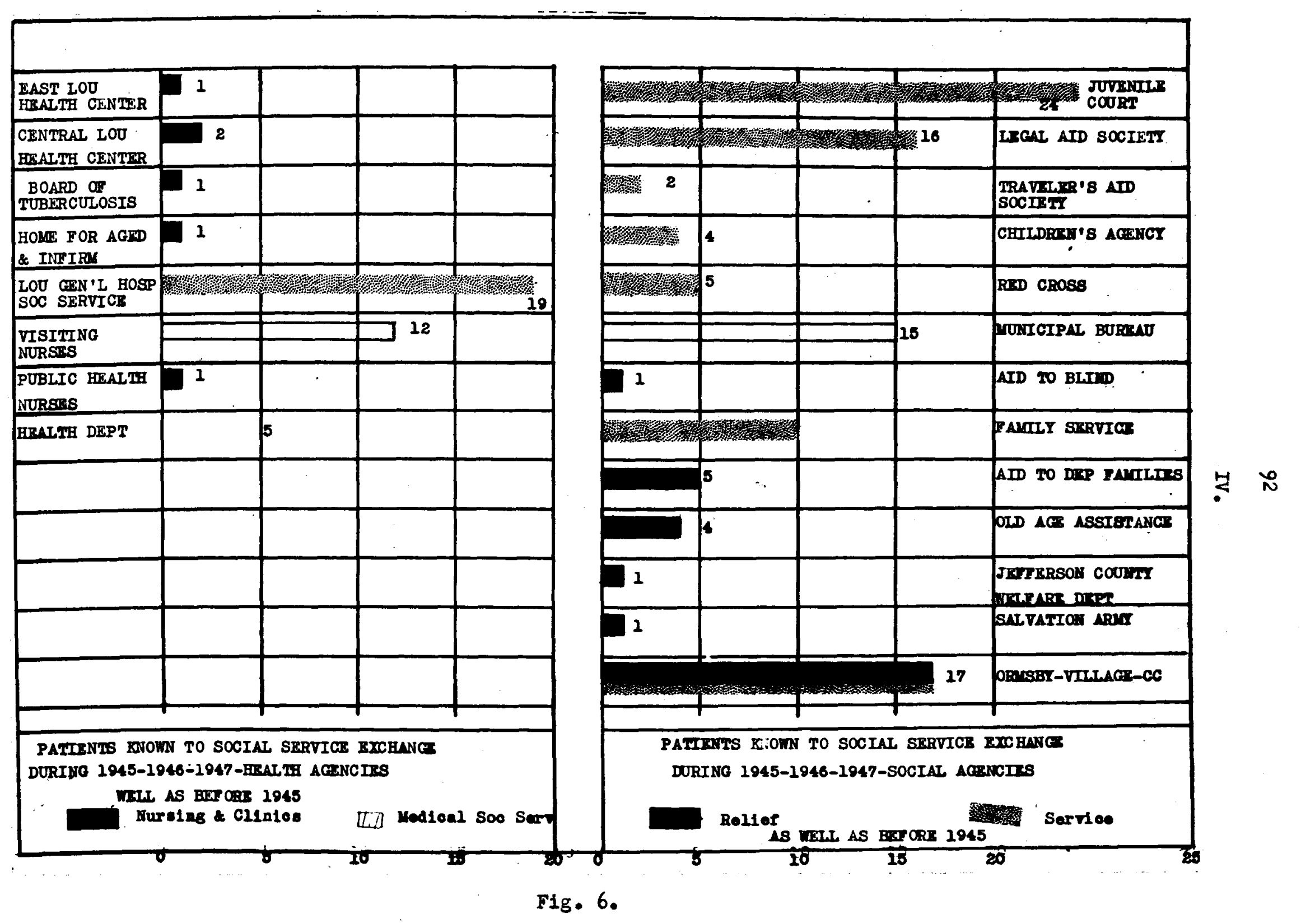




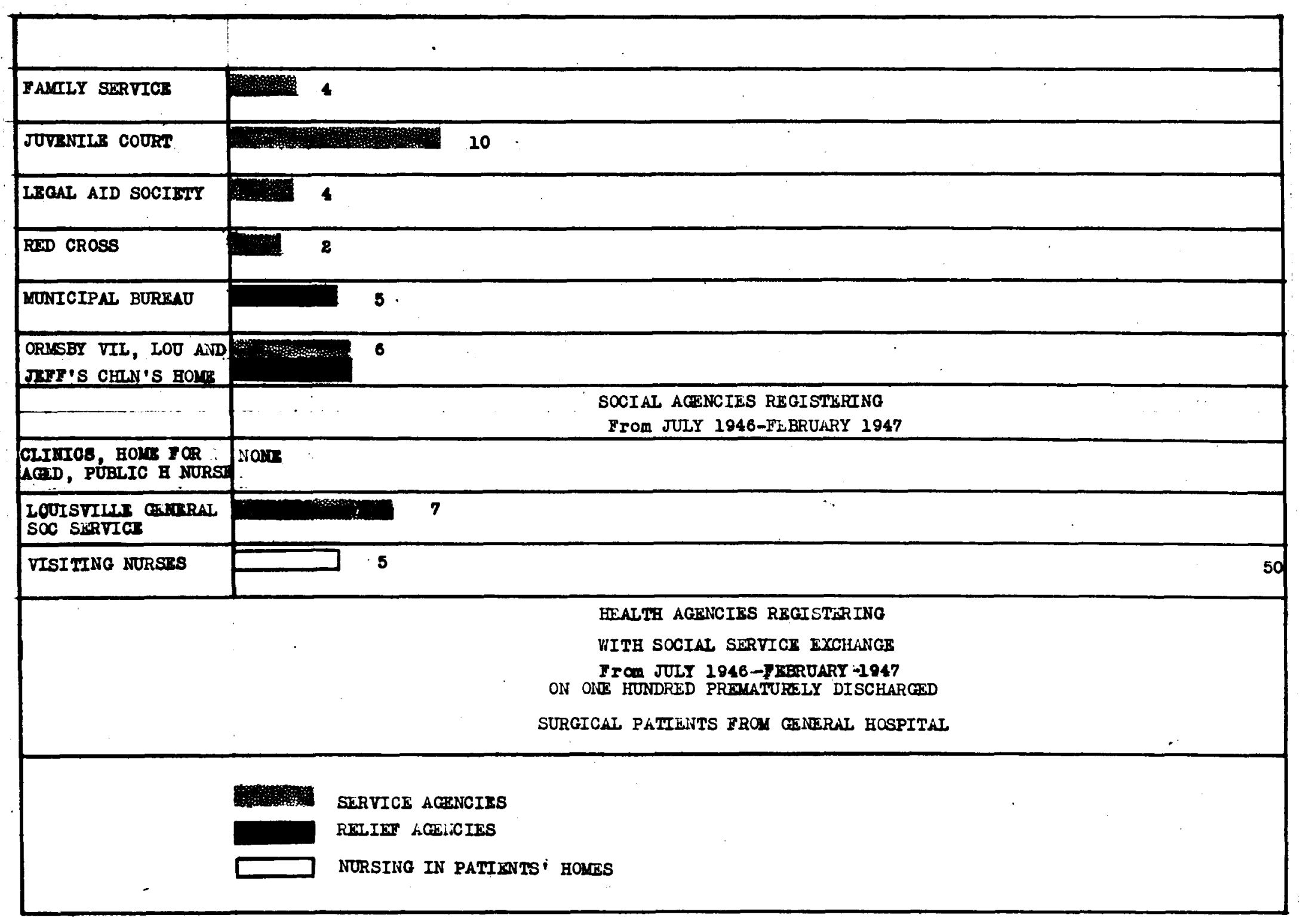




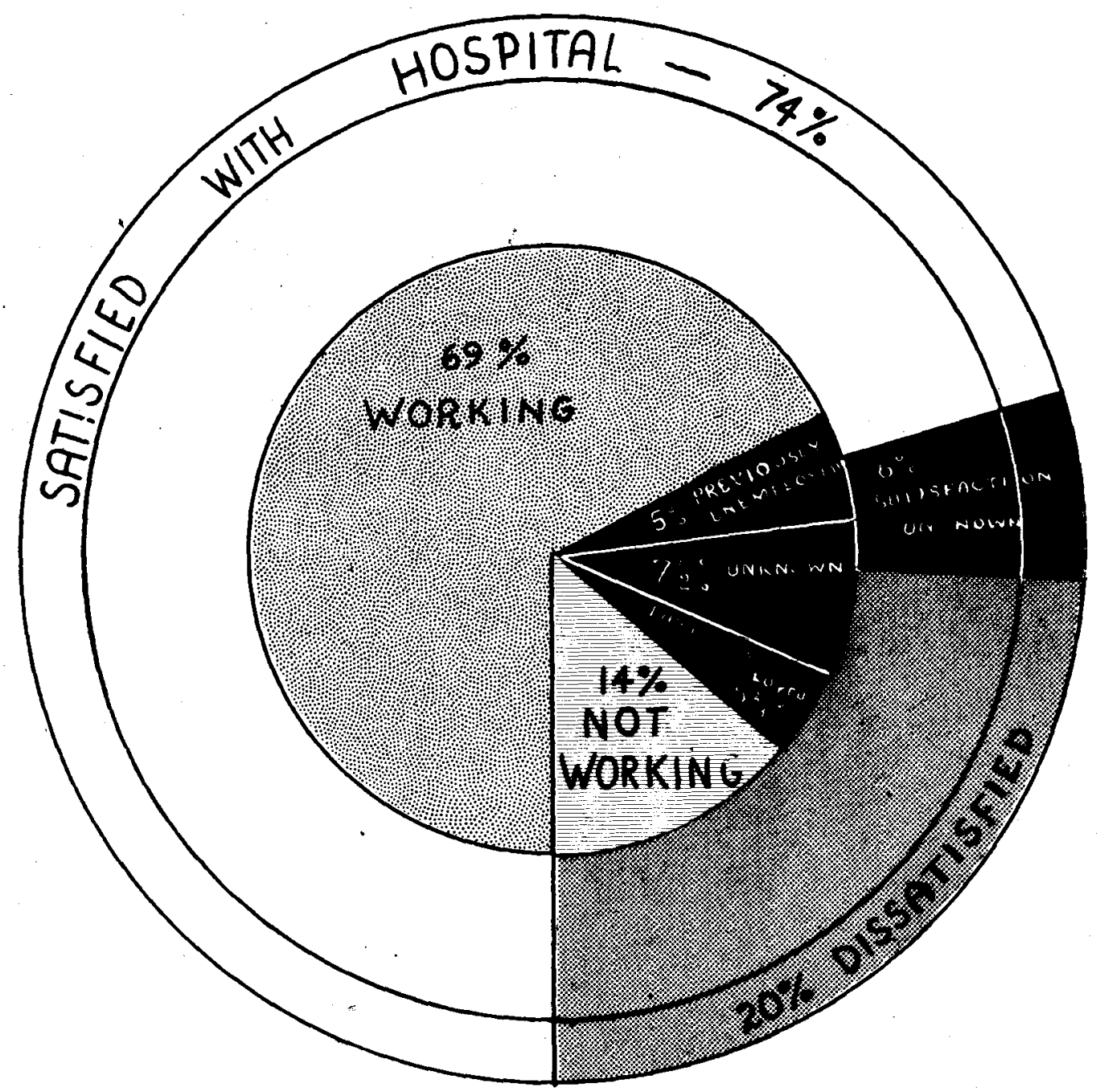

SEVENTY FOUR PREVIATURELY DISCHARGED PATIENTS FROM GENERAL HOSPITAL SHOWING PURCUITAGE VORKING AND PERCEITTGE SATISFIED VITH CARE 


\section{BIBLIOGRAPHY}

\section{References to Specific Literature in Yodical Journals}

and Hospital Administration Periodicele

American Public Wolfare Association. "Organization and Adminiatration Tax-Supported Medical Care," Chicagot Amorican Public Welfare Association, 1939.

Imerican Public Welfare Association. "Plans of Medical Care for Relief Cases in Ton Citios," Chicagos Amorican Public Welfare Assoctation, 1936.

American Public Welfare Association. "Relation of Public Welfare to Medical Care and Institutions," Chicagos American Public Wolfare Association, 1936.

American Public Welfare Association and American Hospital Association. "Hospital Care for the Neody," Hospitals, January 1939.

Baker, Edith. "Health and Dependency." Paper preaented at Colorado School of Social Work, Denver, October 1940. Social Service Revier, Vol. XIV, No.' 4, Decenber 1940.

Boas, Rnst, . D. D. "The Neods of Recipients of Old Age Assistance in New York, 1934," State Department of Social Welfare, Albany, Now York, 1937.

Brown, G. Nasters, and Carling, F. C. "Social Study of Hospital Treatmont," British Modicel Journol, I (April 7, 1945), 478-481.

Flemming, C. R. S. "The Vajor Operations," British Medical Journel, I (Varch 24, 1945), 44 .

Foss, H. L. "Total Hysterectany," Annals of Surgery, CXXI (Kay, 1945), 680-685.

Hughes, F. H., and Lambirth, S. S. "Pulmonary Complications of Appendectomy and Horniorrhaphy," Surgery, XVII (April, 1945), 533-537. 
Yongel, W. F., and Stoltz, R. MTotal Abdominal Hysteroctomy; Observations Based on a Series of 1,925 Pationts," American Journal of Obstetrics and Graecology, XIIV (May 1, 1945), 603-614.

Neardorf, Ruth. Hospital Discharge Study Two Volumes. An Analysis of 526,763 patient discharged in 1933 from New York hospitals. welfare Council of New York City, 1943.

Patricelle, L. "Results of Barly Arising Following Appendoctomies," Northwest Medicine, XIIV (Fobruary, 1945), 54-56.

Skinner, H. L., and Duncan, R. D. "Report of 1,126 Cases of Inguinal Hernia," Surgical Clinics of North America, XXV (February, 1945), $321-323$.

Tartakoff, Ruth. "Social Service Admitting in Public Hospitals," Hoppitale, XII, No, 12 (December, 1947), 22-25.

Tucker, $K_{*}$, Fonder, $Y_{*}$, and Green, R. "Case Oriontation for Visiting Nurses," Family, Journal of Social Case Work, Way 1941.

United Hospital Fund. "Institutions for Convalescent Care, Chronic Care, Howe Care and Nursing Care of the Sick in Their Homes," Hospital Survey for New York, Vol. II. Now York, 1937.

Wisner, Elizaboth. "Admitting as a Social Problem," Transactions of the American Hospital Association, XXXII (October 20-24, 1930), 13 .

Woods, L. "Report on Five Day Stay," Yodern Hospital, LXIV (Narch, 1945) 92.

References to the Hospital Service in Lovisville

Bulletin of the Council of Social Agencies of Louisville, Kentucky. "Chronic Illness in Louisville, October 23, 1937." Council of Social Agencies File.

Carr, Mrs. Dinard. "The Problem of Chronic Illness in Louieville, 1946." Unpublished Master's Thesis, Kent School of Social work, Univorsity of Louigville, 1946.

Casmell, urs. Grace Benton. "Convalescent Care in Louisville, 1943." Unpublished Laster's Thesis, Kent School of Soclal Work, University of Louisville, 1943.

Griswold, Arnold, H. D. "Psychiatry and Surgery," Journal of the American Medical Association, 1942. 


\begin{abstract}
Haines, Anna. Notes on mumeration of Chronic Disease Patients in Loulsville, 1937." Health Council, 1937.

Lipetz, Irving M. "The Louisville Kontucky Home for the Aged and Infirm: A Study of an Institution in 'Pransition." Unpublished Master's Thesis, Kent School of Social Work, University of Louisville, 1942

Louigville and Jefferson County Health Board. Minutes of the Board Moeting in June 1946 on Curtailmont of Health Services for 1946-1947." Unpublishod material from Files of Health Board, Louisville, Kentucky.

Myors, Louise. "A History of the Louisville City Hospital." Unpublished Haster's 'inesis, Department of History, University of Louisville, 1940.
\end{abstract}

\title{
Generel References
}

American Medicel Association. "Hospital Service in the United States, 1941." Journal of the American Medical Association, Vol. CXVI, No. 11, Naroh 15, 1945.

American Medical Association, Bureau of Medical Bconorics. Modical Care of the Aged in Weshington." Journal of the Americen Modical Association, Vol. CXVI, No. 22, May 31, 1941.

Americen Public Melfare Association. "Report of the Committee on Medical Care." Juno 1, 1938.

Americen Public Welfare Association and American Hospital Association. $\Delta$ Report of the Joint Committee on Hospital Care. Chicago American Public Wolfare Association, January 1940.

Baker, Hdith 4. "The Philosophy of Medical Social Work Under Public Auspices." Papers of the American Association of Medical Social. workers. Buffalo, Now York, June 1938.

Boes, Grnst, M. D. The Unseen Plague: Chronic Disease. Now Yorks Columbia University Press, 1940.

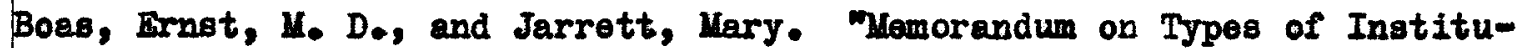
tions Caring for the Chronically Ill and the Aged," New York Welfare Council Publications, Jenuary 1940.

Committee on Chronic Ilness, Welfare Council of New York. Annuel Reports for 1940-1941. Special Committeo Reports on Clinle Care for the Aged Chronically Ill Patient (April 1941) and on Convalescence (August 1942). 
Committee on Costs of Medical Care, 91017 th Streot, Ner York Lee, Roger, $M_{4} D_{0}$, and Jones, Barbara. Publication No. 22. "The Fundamentals of Good Modical Caro," December 1932.

Falk, I. S., Rorem, Rufus, and Ring, Nartha. Publication No, 27. "The Costs of Medical Care," 1932.

Publication No. 28. Medical Care for the American People; The Final Report of the Committee on Costs of Medicel Care," 1932.

Dublin, Louis A. Health and Health, New York: Harpers Bros., 1928.

Goldman, Franz, M. D. Principleg and Problems of Public Medicel Gare. New York: Columbia University.Press, 1945.

Heely, Lucile. "The Use of Housekeeping Service by Medicel Social Workers," Papers of the American Association of Medical Social Workers, Atlantic City, 1940.

National Health Programa Intordepartmontal Committee to Coordinate Health and Welfare Activities. Washington: 1938.

Mational Health Survey 1935-1936, The Magnitude of the Problem, National Institute of Health.

Perrott, G., and Holland, Dorothy. "Population Trende and Problems of Public Health," Milbank Memoriel Fund Quarterly, Vol. XVIII, No. 4, October 1940.

Smith, Iucile M. "Problems in the Development and Administration of Tax-Supported Medical Care Programs," American Association of Medical social Workers, May 1940.

Sturges, Gertrude, K. D. "Public Modical Service as It is Today at State and Local Levels," Social Service Revier, Vol. XIV, No. 3, September 1940.

"What the Hospital Owes the Chronic Disease Patient," Modern Hospital, Vol. XIIV, No. 6, June 1935.

Wing, F. E. "Medical Care of the sick in Their Homea," Bulleting of the Amorican Hospital Association, Vol. IX, No. $25,1935$. 